\title{
Journal of the Geological Survey of Brazil
}

\section{Evidence for ca. 2046 Ma high-grade metamorphism in Paleoproterozoic metasedimentary rocks of the northern Borborema Province, NE Brazil: constraints from U-Pb (LA-ICP-MS) zircon ages}

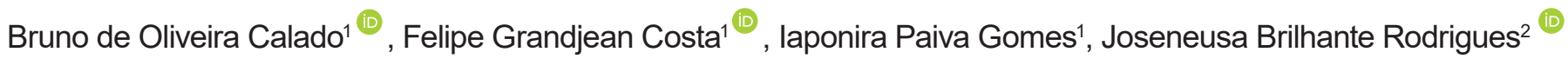

${ }^{1}$ Serviço Geológico do Brasil, Residência de Fortaleza, Avenida Antônio Sales, 1418, Bairro Joaquim Távora, Fortaleza-CE - Brazil, CEP: 60135 -101

${ }^{2}$ Serviço Geológico do Brasil, Divisão de Geodinâmica, SBN, Quadra 2, Bloco H, Bairro Asa Norte, Brasília-DF, Brazil, CEP: $70040-904$

\section{Abstract}

This study presents LA-ICP-MS U-Pb detrital zircon ages on a migmatitic paragneiss of the Jaguaretama Complex, northern Borborema Province, NE-Brazil. This metasedimentary rock comprises a stromatic migmatite with alternating layers of metapelite, metapsammite and garnettourmaline-bearing leucosome. The paleosome displays a well-developed schistosity, with fine to medium-grained textures, and locally garnet porphyroblasts. Backscattered electron images show that many of the zircon grains display metamorphic overgrowths (recrystallization) and cores with igneous oscillatory zoning. The detrital zircon grains show ${ }^{207} \mathrm{~Pb} / 206 \mathrm{~Pb}$ ages clustering from 2.51 to $2.12 \mathrm{Ga}$ (with $90 \%$ conc.), evidencing that the igneous sources were generated mostly during the Transamazonian/Eburnean orogeny. The age of $2137 \pm 9 \mathrm{Ma}$ of the youngest and most concordant detrital zircon (core) is interpreted as the maximum depositional age of the protolith. The youngest and most concordant (conc. $99 \%$ ) ${ }^{207} \mathrm{~Pb} / 206 \mathrm{~Pb}$ apparent age obtained in a metamorphic zircon overgrowth was $2046 \pm 6 \mathrm{Ma}$, which is interpreted as the age of high-grade metamorphism. This age of metamorphism is similar to other records of Paleoproterozoic high-grade metamorphic events in the Borborema Province and other cratonic domains (e.g. São Francisco and West Africa cratons). This age also represents the minimum depositional age of the protolith. Therefore, the depositional age of the studied supracrustal rock may be bracketed between ca. 2.14 and $2.05 \mathrm{Ga}$.

\section{Article Information}

Publication type: Research paper

Submitted: 27 March 2019

Accept: 13 September 2019

On line pub: 02 October 2019

Editor: J.M. Lafon

Keywords:

Paleoproterozoic

Detrital zircon

Metamorphism

Borborema

Geochronology

${ }^{*}$ Corresponding author

Bruno de Oliveira Calado

E-mail address:

bruno.calado@cprm.gov.br

\section{Introduction}

The record of Paleoproterozoic high-grade metamorphism in the central Atlantic cratonic domains (e.g. São Luís-West Africa and São Francisco-Congo cratons) are commonly reported in the literature (e.g. Oliveira and Melo 2002; Oliveira et al. 2010; Teixeira et al. 2017). However, the record of Paleoproterozoic metamorphism is also being identified within the basement rocks (inliers) of the Borborema Province, one of the largest Neoproterozoic fold belts of the West Gondwana supercontinent (e.g., Neves et al. 2006; Hollanda et al. 2011; Santos et al. 2013; Neves et al. 2015; Santos et al. 2015).

The Jaguaretama Complex is located in the northern portion of the Borborema Province between the Senador Pompeu and Tatajuba-Jaguaribe shears zones, according to Oliveira and Medeiros (2018) (Fig. 1C). This complex is mainly composed of tonalitic to granodioritic orthogneisses and high-grade metasedimentary rocks with variable degree of migmatization (Cavalcante et al. 2003).

According to Fetter et al. (2000), U-Pb zircon ages (IDTIMS) from associated metaplutonic rocks of the Jaguaretama Complex yielded crystallization ages ranging from ca. 2.21 to $1.98 \mathrm{Ga}$, and their $\mathrm{Nd}$ isotopes (TDM of 2.61 to $2.50 \mathrm{Ga}$ ) indicate the incorporation of an older crustal component. Similar $\mathrm{U}-\mathrm{Pb}$ ages and unradiogenic $\mathrm{Nd}$ signatures are found in other Paleoproterozoic orthogneisses across the northern Borborema Province, such as the Caicó Complex (Fetter et al. 2000; Souza et al. 2007; Hollanda et al. 2011; Medeiros et al. 2012; Sá et al. 2014; Oliveira and Medeiros 2018).

For the metasedimentary rocks of the Jaguaretama Complex, Fetter (1999) attributed that they were probably deposited early in the Transamazonian orogenesis, sometime between ca. 2.42 and $2.21 \mathrm{Ga}$, based on $\mathrm{U}-\mathrm{Pb}$ monazite and $\mathrm{Nd}$ T(DM) ages. Fetter (1999) obtained a U-Pb age for a firstgeneration leucosome in a migmatitic paragneiss, with the 
analysis of three monazite grains yielding a discordant upper intercept age of $2217 \pm 14 \mathrm{Ma}$ interpreted as the age of the high-grade metamorphism. Despite this preliminary work by Fetter (1999), no other geochronological constraints on the timing of high-grade metamorphism exist for the Jaguaretama Complex. Additionally, the age of $2217 \pm 14$ Ma obtained by Fetter (1999) is not in agreement with other metamorphic ages (ca. 2.07-2.04 Ga) from the Borborema Province (e.g. Silva et al. 2002; Gomes 2013; Neves et al. 2006; Costa and Palheta 2017). For example, according to Neves et al. (2006), in the Transversal subprovince of the central Borborema Province (between the Patos and Pernambuco shear zones, Fig. 1C), the high-grade metamorphism was dated at $2041 \pm 15$ Ma by low $\mathrm{Th} / \mathrm{U}$ metamorphic zircons from a leucosome in a migmatitic paragneiss. According to these authors, this metamorphic age is related to the major collisional event of the Transamazonian/ Eburnean orogeny, affecting surrounding cratonic domains (e.g. West Africa and São Francisco cratons).

In this study, we present U-Pb (LA-ICP-MS) ages of detrital zircons from a high-grade metasedimentary sample of the Jaguaretama Complex, which record the effects of the Paleoproterozoic high-grade metamorphism in zircon overgrowths and provide some provenance information from zircon cores.

\section{Regional Geology}

The Borborema Province represents a Late Neoproterozoic mobile belt located between the São Luís-West African and São Francisco-Congo cratons (Fig. 1A). It developed during the ca. 650-535 Ma Pan-African/Brasiliano orogenic cycle, related to the formation of the West-Gondwana supercontinent (Almeida et al. 1981). The basement includes Archean and Paleoproterozoic rocks, as well as volcano sedimentary units of Paleoproterozoic-Neoproteozoic ages. The Borborema Province is commonly subdivided into the Médio Coreaú, Ceará Central, Rio Grande do Norte, Transversal and Meridional subprovinces (Brito Neves et al. 2000; Neves 2003; Van Schmus et al. 2011) (Fig. 1B).

Based on $\mathrm{U}-\mathrm{Pb}$ zircon ages and $\mathrm{Nd}$ isotopes of basement rocks, the northern Borborema Province, bound to the south by the Patos lineament (or shear zone), has been divided into three main subprovinces: Médio Coreaú, Ceará Central, and Rio Grande do Norte (Fetter et al. 2000) (Fig. 1B and 1C). The Médio Coreaú subprovince comprises mostly Siderian TTG gneisses, with $\mathrm{U}-\mathrm{Pb}$ (TIMS) zircon ages of 2.35-2.30 $\mathrm{Ga}$, and $\mathrm{Nd}$ model ages between 2.61 and $2.38 \mathrm{Ga}$ (Fetter, 1999; Santos et al. 2009). The Ceará Central subprovince comprises mainly Rhyacian ages, from ca. 2.19 to $2.06 \mathrm{Ga}$ (Fetter et al. 2000; Martins et al. 2009; Costa et al. 2015, 2018) and $\mathrm{Nd}$ ages between 2.37 and $2.23 \mathrm{Ga}$ (Fetter et al. 2000; Martins et al. 2009), and the Rio Grande do Norte subprovince records a crustal growth period mainly between 2.22 and 2.15 Ga, (e.g., Caicó Complex) with Nd ages between 3.2 and 2.4 Ga (Fetter et al. 2000; Hollanda et al. 2011).

Archean rocks have also been found as basement inliers in the Borborema Province. In the Ceará Central Domain (Fig. 1), U-Pb zircon dating from grey gneisses indicate two different episodes of Archean crust formation, represented by the Mombaça (2.85-2.77 Ga) and Pedra Branca (2.70-2.68 Ga) units (or blocks) from the Tróia Massif (Fetter 1999; Ganade et al. 2017). Other Archean ages are found in the Granjeiro
Complex, located in the Rio Grande do Norte subprovince, initially defined by Silva et al. (1997). It is a thrust-related, bimodal, tonalitic to granodioritic (occasionally trondjhemitic) banded gneiss, locally intercalated with mafic bands of tholeiitic amphibolites (Silva et al. 1997). U-Pb SHRIMP zircon analyses of a biotite-hornblende tonalitic gneiss recorded $2541 \pm 11 \mathrm{Ma}$ for this complex (Silva et al. 1997). More recentely, Freimann (2014) reported a U-Pb (LA-ICPMS) zircon ages of granodioritic orthogneiss ( $2792 \pm 8 \mathrm{Ma})$, metaultramafic xenolith in migmatite gneiss $(3026 \pm 45 \mathrm{Ma})$ and banded gneiss $(3184 \pm 45 \mathrm{Ma})$ of the Granjeiro Complex, which are similar to Archean rocks (3.4$2.7 \mathrm{Ga}$ ) of the São José do Campestre Massif (Dantas et al. 2004; Souza et al. 2016) in the Rio Grande do Norte Domain (Fig. 1C). Ancelmi (2016) also identified ages of 2.71-2.59 Ga for amphibolites and metarhyolites of the Granjeiro Complex. More recently, Archean rocks have also been identified in the Transversal Borborema Province (2.6 Ga, Riacho das Lages Suite, Santos et al. 2017).

All these Archean fragments of the Borborema Province are enveloped by granitoids, gneisses, migmatites and metavolcano-sedimentary sequences of Siderian (2.5-2.3 Ga) (Ancelmi 2016; Freimann 2014) and Rhyacian (2.3-2.0 Ga) ages (Fetter et al. 2000; Dantas et al. 2004; Souza et al. 2007, 2016; Hollanda et al. 2011; Costa et al. 2018). One of theses metavolcano-sedimentary sequences comprises amphibolites that were dated at $2236 \pm 55 \mathrm{Ma}$ (whole rock Sm$\mathrm{Nd}$ isochron, Martins et al. 2009) and display geochemistry similarities (element ratios such as ( $\mathrm{Nb} / \mathrm{La}$ ) n vs. (Nb/Th)n and $\mathrm{Th} / \mathrm{Ta}$ vs. La/Yb) with Phanerozoic oceanic plateau basalts or back-arc basin basalts (Martins et al. 2009).

\subsection{Local geology}

The study area is primarily composed of (1)Paleoproterozoic orthogneisses (ca. 2.1 Ga) of tonalite to granodioritic compositions and migmatites related to supracrustal rocks, known as the Canindé do Ceará and Jaguaretama complexes, separated by the Senador Pompeu shear transcurrent zone; (2) monzogranitic to syenogranitic augen gneisses known as the Serra do Deserto Magmatic Suite of Statherian age, which border the Orós Group in the southern portion of the study area; (3) Orós Group, specifically the Santarem Formation, which comprise pelitic garnet-biotite schist, mica schists and quartzite, with a few lenses of calc-silicate rocks and amphibolite rock; (4) large volumes of Neoproterozoic granitoids represented by Lagoa da Serra and Itaporanga magmatic suites; (5) late Tertiary sediment deposits of the Barreiras Group, highlighting the conglomerates of Faceira Formation; and (6) alluvial and colluvium deposits of Neogene age. Fig. 2 presents a simplified version of the geologic map of the study area.

\section{Analytical procedures}

After thin section observation under petrographic microscopy, a selected sample was prepared for U-Pb zircon dating by the following procedures. The selected rock sample was crushed with a jaw crusher and powdered to approximately $500 \mu \mathrm{m}$. Heavy mineral were concentrated by panning and subsequently the magnetic portion was separated using a Frantz isodynamic separator. Zircon grains were separated manually in binocular loupe for mount preparation. The grains 


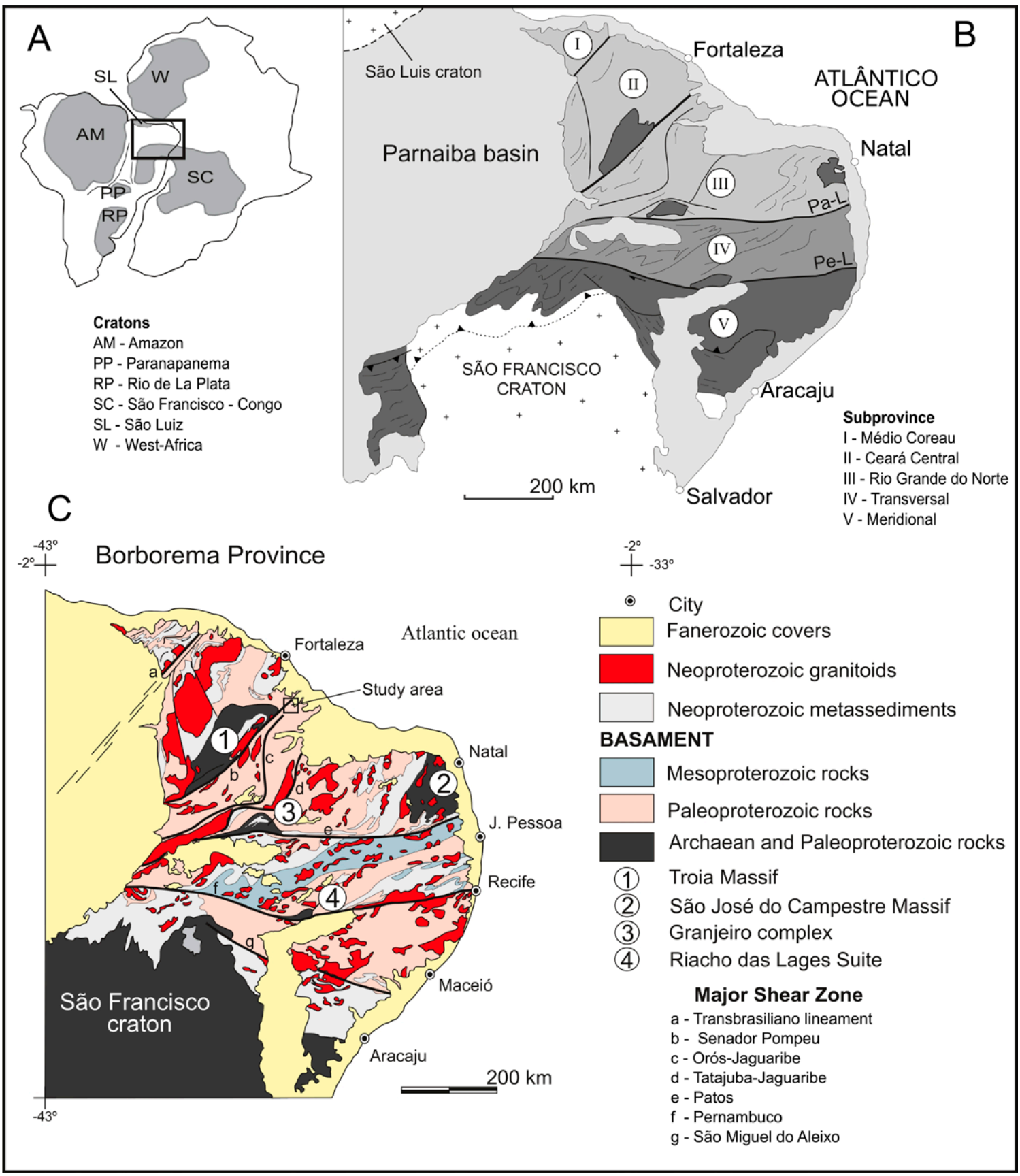

FIGURE 1 - (A) Paleogeographic configuration of the Gondwana Supercontinent at ca. $600 \mathrm{Ma}$. (B) Tectonic subprovinces of the Borborema Province. (C) Simplified geological map of the Borborema Province with location of the study area, modified from Oliveira and Medeiros (2018).

were embedded in epoxy resin and polished in $0.25 \mu \mathrm{m}$ diamond paste to expose the interior of the grains.

Prior to the isotopic analytical work, zircon grains were characterized by backscattered (BSE) electron imaging using a Scanning Electron Microscope Quanta 450 of the Laboratório de Estudos Geocronológicos, Geodinâmicos e Ambientais of the Universidade de Brasilia (UnB, Brasília, Brazil).

The isotopic determinations were conducted in the same university (Unb), by LA-MC-ICP-MS (laser ablation multiplecollector inductively coupled plasma mass spectrometry) following the procedure presented by Bühn et al. (2009). Insitu zircon $\mathrm{U}-\mathrm{Pb}$ analyses were carried out using a ThermoFinnigan Neptune mass spectrometer coupled to an $\mathrm{Nd}$ YAG laser $(\lambda=213 \mathrm{~nm}$ ) Laser Ablation System (New Wave
Research, USA). The ablation was done with spot size of 30 $\mu \mathrm{m}$, a frequency of $10 \mathrm{~Hz}$ and an intensity of 0.19-1.02 J/cm2. The ablated material was carried by mixture of $\operatorname{Ar}(\sim 0.90 \mathrm{~L} /$ $\mathrm{min})$ and $\mathrm{He}(\sim 0.40 \mathrm{~L} / \mathrm{min})$ in analyses of 40 cycles of $1 \mathrm{~s}$.

The laser-induced elemental fractionation and instrumental mass discrimination are corrected using the isotopic ratios of the homogeneous GJ-1 zircon (608.5 $\pm 1.5 \mathrm{Ma}$; Jackson et al. 2004). The accuracy was controlled using the standard zircon 91500 (1065 $\pm 0.3 \mathrm{Ma}$; Wiedenbeck et al. 1995). Raw data were reduced using an Excel spreadsheet and corrections were done for background, instrumental mass bias drift and common $\mathrm{Pb}$. The histogram and probability density plot for the obtained ${ }^{207} \mathrm{~Pb} /{ }^{206} \mathrm{~Pb}$ ages were done with ISOPLOT 3.0 (Ludwig, 2008). 


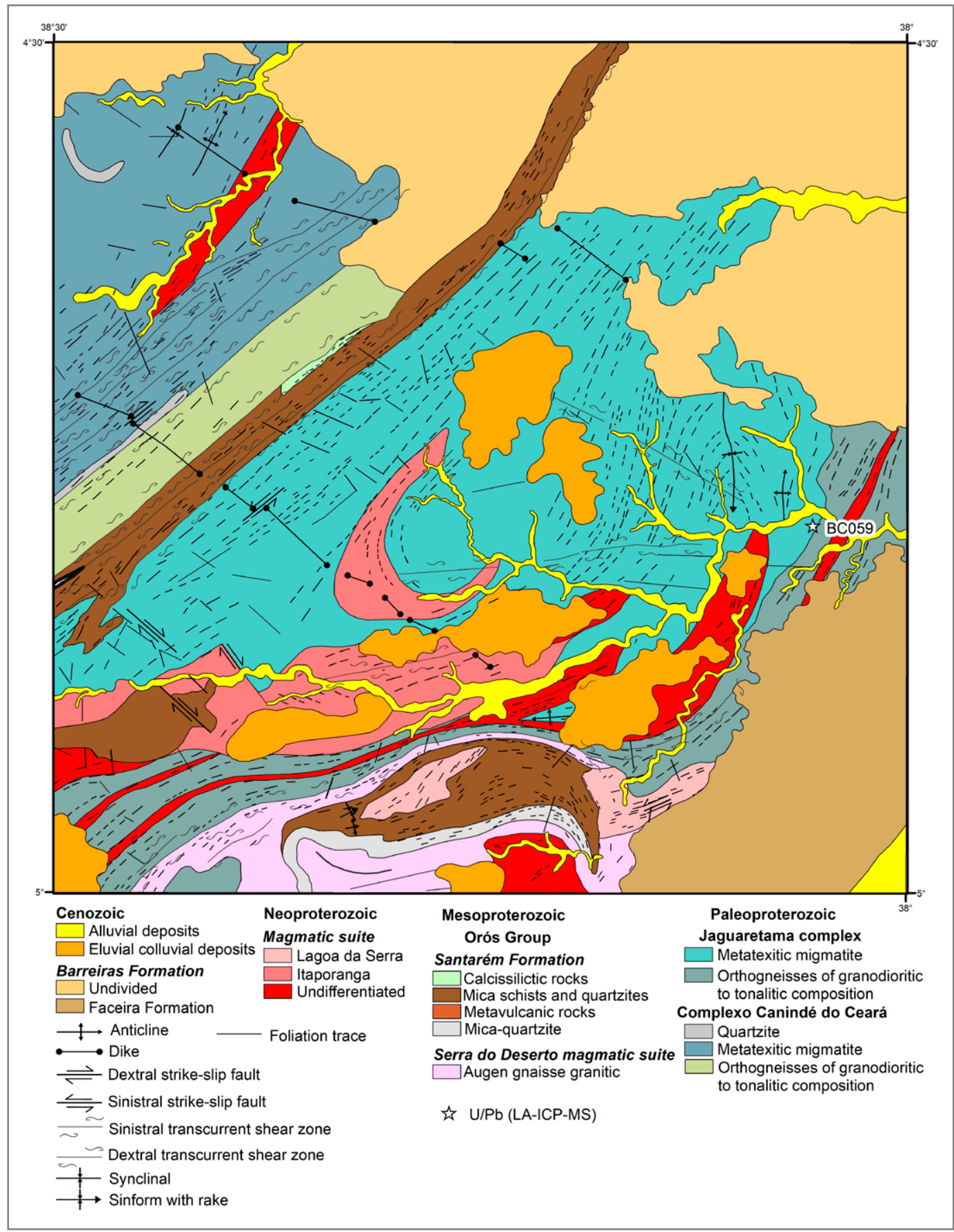

FIGURE 2 - Geological map and sample location (modified from Calado 2017).

\section{Results}

\subsection{Petrography}

The sample selected for geochronology is a migmatitic paragneiss from the Jaguaretama Complex (Sample BC059, UTM 24S SIRGAS 2000: 604844, 9470969). The analyzed migmatitic paragneiss presents alternating layers of metapelite and metapsammite and garnet-tourmaline bearing leucosomes (Fig. 3A). The paleosome portions display a well-developed schistosity and generally have a fine to medium-grained granolepidoblastic texture (Fig. 3B), mainly composed of biotite (36\%), quartz $(30 \%)$, muscovite $(23 \%)$, plagioclase $(3 \%)$, opaque $(5 \%)$ and traces of zircon and apatite. Abundant leucocratic leucosomes and veinlets occur generally concordant with the foliation trend and locally have boudinage patterns (Figs. $3 \mathrm{~A}$ and $\mathrm{B}$ ). The leucosomes have generally fine to medium-grained textures and are usually strongly foliated. The major phases include quartz $(38 \%)$, plagioclase $(23 \%)$, muscovite $(24 \%)$, biotite $(8 \%)$ and accessory phases of garnet $(3 \%)$, tourmaline $(2 \%)$ and zircon (2\%). The garnet porphyroblasts are euhedral, some sub-rounded and usually with traces of biotite and muscovite inclusions (Fig. 3C). Tourmaline is found as euhedral crystals, 
commonly with opaque and rutile inclusions (Fig. 3D and $3 E$ ). Large graphite crystals are often present, showing synto post-tectonic textures, generally as porphyroblasts along the main foliation trend (Fig. 3F).

\subsection{U-Pb zircon ages}

Single-grain laser ablation U-Pb dating was conducted on detrital zircon grains of sample BC059. The backscattered electron images show that most of the analyzed zircon grains display a core-rim relationship (Fig. 4). The zircon grains are characterized by fractured or shattered cores surrounded by overgrown zone that exhibit evidence for multiple stages of growth, corrosion and variable degree of fracturing (Fig. 4).
Among all analyzed spots $(n=69)$, only the concordant data $( \pm 10 \%)$ were utilized in the provenance study (Table 1 ), and illustrated in Fig. 4. Zircon cores of the analyzed sample yielded ${ }^{207} \mathrm{~Pb} /{ }^{206} \mathrm{~Pb}$ ages between ca. 2121 and $2511 \mathrm{Ma}(\mathrm{n}=$ 29 , conc. $90-110 \%$ ) (Table 1), are presented in the histogram and probability density plot (Fig. 5). The youngest most concordant $\left(99 \%\right.$ conc) detrital zircon yielded a ${ }^{207} \mathrm{~Pb} /{ }^{206} \mathrm{~Pb}$ age of $2137 \pm 9 \mathrm{Ma}$ (Table 1 ).

A group of 12 spots presented low Th/U ratios $(<0,012)$, mostly representing the rims of the detrital zircon grains (Table 1 and Fig. 4). The ${ }^{207} \mathrm{~Pb} /{ }^{206} \mathrm{~Pb}$ ages for these metamorphic zircon overgrowths varies from $2138 \pm 5$ to $1973 \pm 9$ Ma (Table 1). However, we excluded the spots Z4, Z53, 43B and Z56, that may represent core-rim mix (see spot

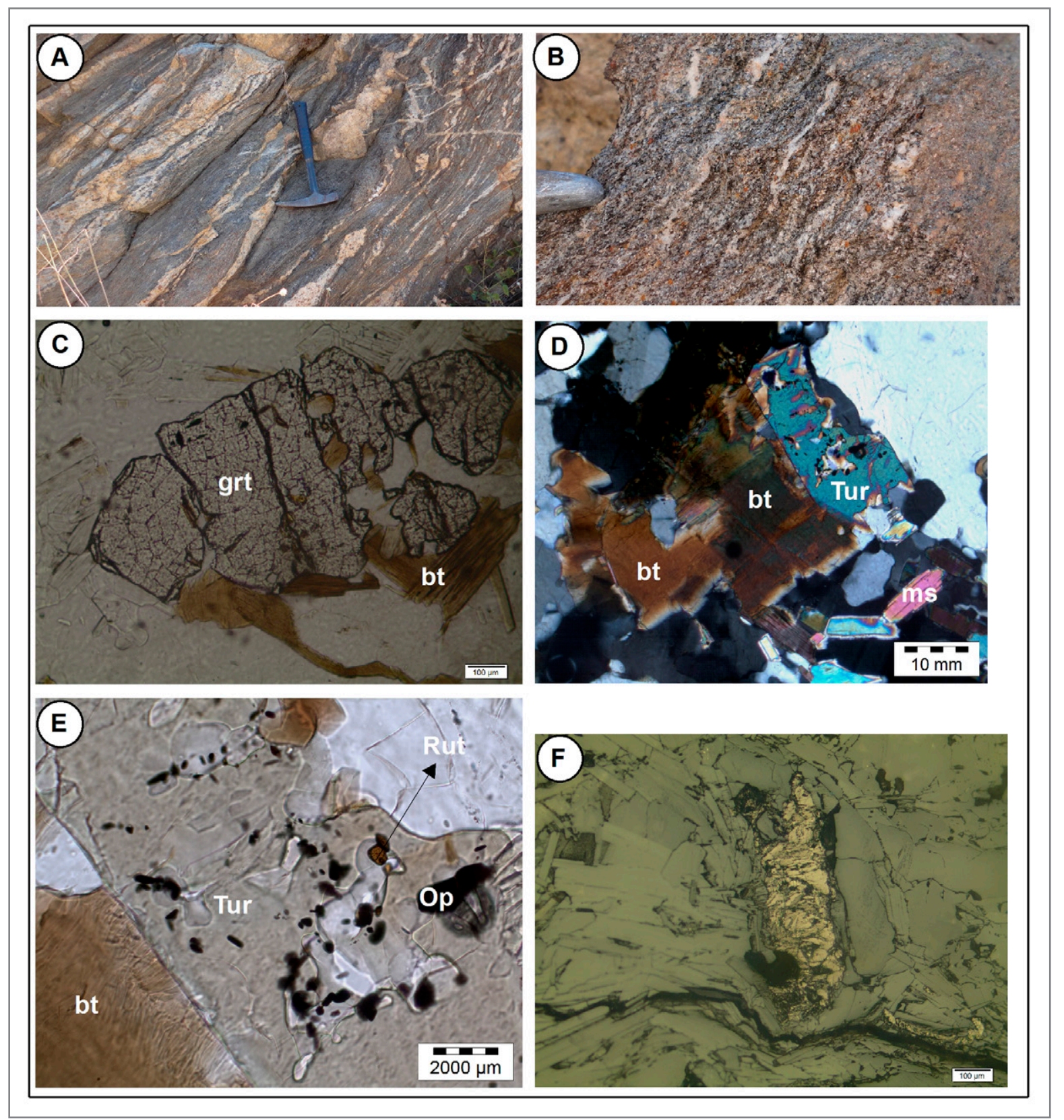

FIGURE 3 - (A) Field photograph of the migmatitic paragneiss from the Jaguaretama Complex; (B) detail for the paleosome with garnet porphyroblast; (C) Photomicrography with features of biotite (bt) inclusion in garnet (grt) porphyroblast from a paleosome sample; (D) Photomicrography showing detail for tourmaline, biotite and muscovite from a quartz-feldspathic leucosome vein (E) Photomicrography with detail for rutile (Rut) and opaque (Op) inclusions in a tourmaline (Tur) euhedral grain from the quartz-feldspathic leucosome vein; ( $F$ ) coarse graphite flake-type surrounded by opaque phases in a mesosome layer. 


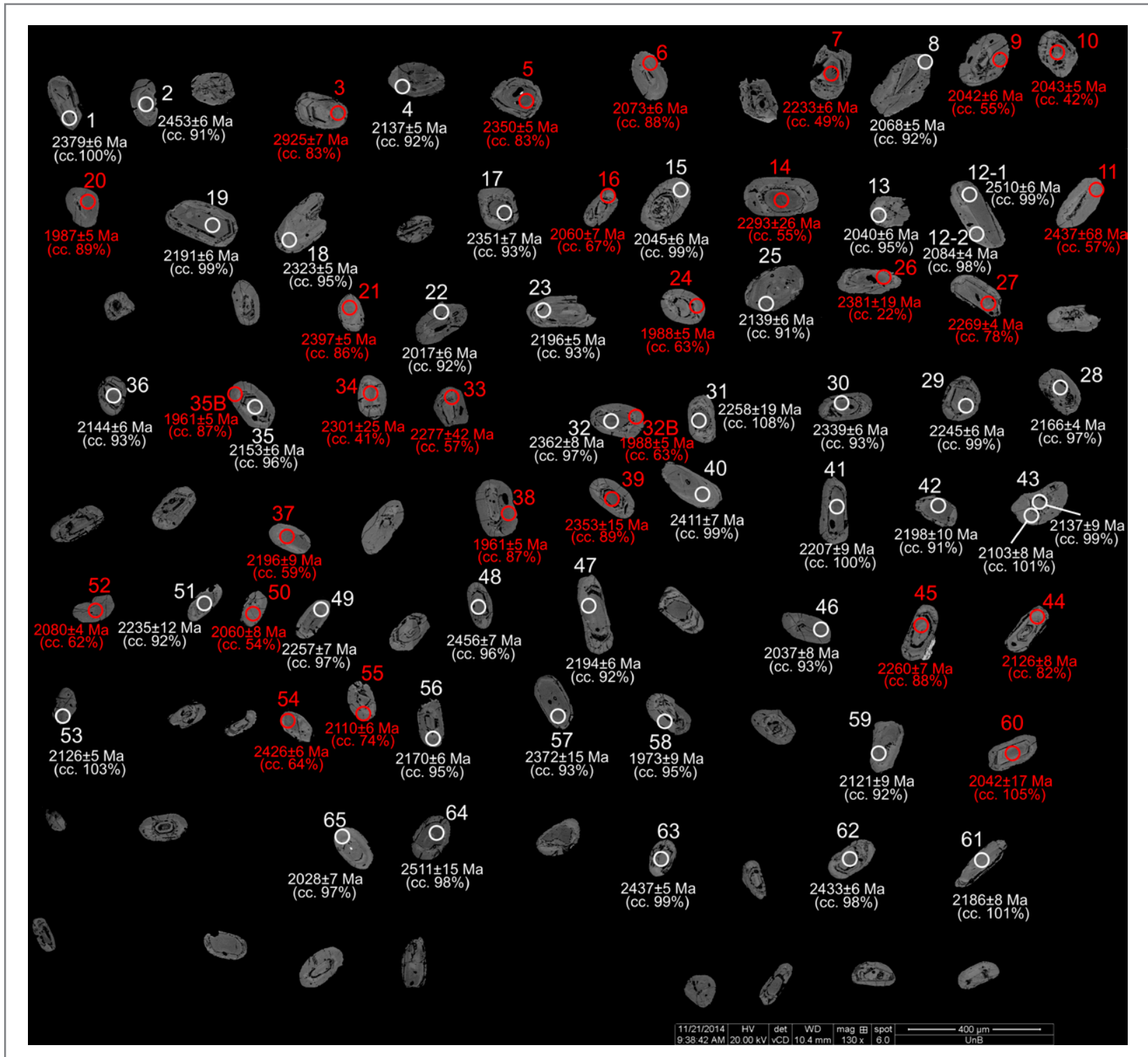

FIGURE 4 - Backscattered electrons images of detrital zircons grains with location of the spots of LA-ICPMS U-Pb dating and related ${ }^{207} \mathrm{~Pb} /{ }^{206} \mathrm{~Pb}$ ages.

positions in the backscattered electron images, Fig. 4). The youngest and most concordant ${ }^{207} \mathrm{~Pb} /{ }^{206} \mathrm{~Pb}$ age obtained in a metamorphic zircon overgrowth was $2046 \pm 6$ Ma (spot 023 Z15, conc. 99\%) (Table 1).

\section{Discussion}

\subsection{Provenance analysis}

Many of the analyzed zircon cores of the supracrustal sample (Jaguaretama Complex) presented Rhyacian ages (Table 1) (Fig. 5), which indicate an igneous source associated with the ca. 2.2-2.0 Ga Transamazonian/Eburnean orogeny. This Orogeny is a well-accepted example of Paleoproterozoic crustal growth and reworking during subduction-accretion processes, followed by major continental collision and supercontinent formation (e.g. Abouchami et al. 1990; Ledru et al. 1994; Cordani and Sato 1999; Brito Neves et al. 2000;
Neves et al. 2006; Baratouxet al. 2011; De Kock et al. 2011; Santos et al. 2015; Neves et al. 2015; Block et al. 2016; Loose and Schenk 2017). The Orogeny is known as the Eburnean orogeny in the West African craton (e.g. Liégeois et al. 1991; Feybesse et al. 2006; Block et al. 2016; Petersson et al. 2016, 2017) and the Transamazonian orogeny in the correlated terranes of the São Luis Craton (Klein and Moura 2008; Klein et al. 2012), Guyana Shield (Amazon Craton) (Vanderhaeghe et al. 1998; Delor et al. 2003; Rosa-Costa et al. 2006; McReath and Faraco 2006) and northern São Francisco Craton (Silva et al. 2001; Costa et al. 2011; Oliveira et al. 2011) (Fig. 1A).

Many of the Transamazonian/Eburnean terranes are interpreted as island and/or continental arc sequences that evolved during ca. 2.2-2.1 Ga accretionary tectonics that culminate at ca. 2.1-2.0 Ga in continental collision and regional metamorphism (Liégeois et al. 1991; Vanderhaeghe et al. 1998; Delor et al. 2003; Feybesse et al. 2006; McReath and Faraco 2006; Costa et al. 2011; Oliveira et al. 2011; Costa etal. 2015, 2018). 
In the Borborema Province, NE-Brazil (Fig. 1), the record of the Paleoproterozoic (ca. 2.2-2.0 Ga) Transamazonian/ Eburnean orogeny is commonly reported in the literature for basement rocks (e.g., Neves et al. 2006; Hollanda et al. 2011; Santos et al. 2013; Neves et al. 2015; Santos et al. 2015). In this contribution, the analyzed sample from the Paleoproterozoic Jaguaretama metasedimentary sequence, indicates that this sequence is also Paleoproterozoic in age, and the detrital zircon ages mimic the ages of many Rhyacian orthogneisses dated in basement rocks of the northern Borborema Province (e.g., Fetter et al. 2000; Souza et al. 2007; Martins et al. 2009; Hollanda et al. 2011; Silva et al. 2014; Costa et al. 2015; Souza et al. 2016; Costa et al. 2018). According to these authors, most of these ca. 2.22-2.19 Ga Rhyacian orthogneisses are interpreted as the record of the pre-collisional stage (arc magmatism) within the Transamazonian/Eburnean orogenic cycle.

The concordant ${ }^{207} \mathrm{~Pb} /{ }^{206} \mathrm{~Pb}$ age of $2137 \pm 9$ (99\% conc.) (spot Z43N, Table 1, Fig. 4) for the youngest detrital zircon grain represents the maximum depositional age of the protolith, and the potencial sources with similar ages may be represented by the orthogneisses of the Boa Viagem Complex, interpreted to record continental arc plutonism at the northern portion of the Troia Massif, with U-Pb (SHRIMP) zircon ages of $2150 \pm 29 \mathrm{Ma}$ and $2124 \pm 35 \mathrm{Ma}$ (Silva et al. 2014).

For the studied sample, the youngest and most concordant ${ }^{207} \mathrm{~Pb} /{ }^{206} \mathrm{~Pb}$ age obtained in a metamorphic zircon overgrowth (2046 $\pm 6 \mathrm{Ma}$ ) is interpreted here as the age of metamorphism and the minimum depositional age of the protolith. Therefore, the depositional age of the studied supracrustal rocks of the Jaguaretama Complex may be bracketed between ca. 2137 and $2046 \mathrm{Ma}$. This age interval for the deposition, place the sedimentary setting in the final stages of the ca. 2.2-2.0 Ga Transamazonian/Eburnean accretionary-collisional orogeny.

In addition, the $\mathrm{U}-\mathrm{Pb}$ zircon ages of ca. 2.09 and $2.68 \mathrm{Ga}$ obtained by Costa et al. (2018) for potassium-rich collisional granitoids of the Bananeira Suite in the Troia Massif, may represent the onset of major continental collision and crustal reworking (partial melting) of the above mentioned precollisional crust. Thus, the absence of detrital zircon grains of these ages (e.g. $2.09 \mathrm{Ga}$ ) in the analyzed metassedimentary sample of the Jaguaretama Complex, suggests that sedimentary deposition was no longer active at this time.

The maximum depositional age obtained in this work $(2137 \pm 9$ $\mathrm{Ma}$ ) is also similar to those obtained for the Paleoproterozoic Itapecerica graphite-rich sequence in the southeastern São Francisco Craton, with the age of $2129 \pm 11 \mathrm{Ma}$ for youngest detrital zircon population (Teixeira et al. 2017). It is also similar to the maximum depositional age of $2133 \pm 4 \mathrm{Ma}$ of the Tarkwaian sequence of the West African Craton (Pigois et al. 2003) and the maximum depositional age of ca. $2120 \mathrm{Ma}$ for a quartzite sample from the Itapicuru greenstone belt in the northern São Francisco Craton (Grisolia and Oliveira 2012). For all these sedimentary sequences, the tectonic settings are proposed to involve sedimentation along a foreland basin, related to arc-continent and/or continent-continent collision (Pigois et al. 2003; Grisolia and Oliveira 2012; Teixeira et al. 2017).

The U-Pb ages of $\sim 2.5 \mathrm{Ga}$ for the two oldest zircon grains, support the participation of a Neoarchean crustal source (Fig. 5). Potential sources for these two zircon grains can be attributed to Neoarchean gray gneisses of the Granjeiro Complex, which commonly record $\mathrm{U}-\mathrm{Pb}$ zircon ages of ca $2.5 \mathrm{Ga}$ (Silva et al. 1997; Ancelmi 2016). Igneous rocks with older zircons ages
(2.7-3.1 Ga) have also been identified in the Granjeiro Complex (Freimann 2014; Hollanda et al. 2011; Ancelmi 2016).

Eleven detrital zircon grains presented Siderian ${ }^{207} \mathrm{~Pb} /{ }^{206} \mathrm{~Pb}$ ages (Table 1, Fig. 5). Siderian $\mathrm{U}-\mathrm{Pb}$ zircon ages have been reported for the Granjeiro Complex, for samples of a biotite-gneiss $(2356 \pm 12 \mathrm{Ma})$ and amphibolite (2367 \pm $12 \mathrm{Ma}$ ) (Freimann 2014). Others Siderian ages are reported for the TTG basement gneisses in the northwestern part of the Borborema Province, that represent a continental fragment formed mainly by $2.35-2.30 \mathrm{Ga}$ juvenile crust (Santos et al. 2009) (Médio Coreaú subprovince, Fig. 1B). According to Santos et al. (2009), the 2.35-2.30 Ga TTG gneisses of the Médio Coreaú Domain correspond to an early stage of juvenile crust generation, that probably developed in intra-oceanic arcs, prior to the subsequent widespread 2.2-2.1 Ga pre-collisional magmatic record of the Transamazonian/Eburnean orogeny. In the Birimian terranes (West African craton), Gasquet et al. (2003) recorded an age of $2312 \pm 17$ Ma for xenocrystic zircons in a $2170 \pm 19 \mathrm{Ma}$ tonalite from the Dabakala area, and suggested that these xenocrystic zircons may represent an early stage of crustal growth in the Transamazonian/ Eburnean orogeny (Gasquet et al. 2003).

\subsection{Age of the Paleoproterozoic high-grade metamor- phism}

The presence of zircon growth under anatectic conditions, commonly as overgrowths on pre-existing zircon, are features that indicate that crustal thickening and continental collision took place during the late stages of the Transamazonian/ Eburnean orogeny (e.g., Block et al. 2016; McFarlene, 2018).

The metamorphic age from the most concordant zircon overgrowths of the studied sample from the Jaguaretama Complex (2046 $\pm 6 \mathrm{Ma}$, Table 1) is similar (within error) to the highgrade metamorphic record of $2044 \pm 5$ Ma on zircon grains in a mafic layer of banded orthogneiss in the Eastern Pernambuco Domain of the Borborema Province (Neves et al. 2006). Similarly, this is also identical to the low Th/U metamorphic zircon dated at $2041 \pm 15 \mathrm{Ma}$ in the leucosome of a migmatitic paragneiss in this same domain (Neves et al. 2006). These authors interpreted these ages to record the major collisional event, related to the Transamazonian/Eburnean orogeny.

Garcia et al (2014) reported a U-Pb (LA-ICPMS) zircon age of ca. $2070 \pm 19$ Ma for porphyritic aluminous granite in the Canindé Unit. S-type granites are typical of collisional setting and therefore, this age of ca. 2070 Ma may indicate that major continental collision had already started at this time. This age is identical to the age of metamorphism obtained on a xenolith of paragneiss in the S-type Itapiuna granite, attributed to the Canindé Complex of Ceará (Costa and Palheta 2017). Using the data from these authors, we calculated (not shown here) an upper intercept age of $2071 \pm 18 \mathrm{Ma}(\mathrm{MSWD}=0.66, \mathrm{n}=5$ ) for the metamorphic zircon $(n=35$, Th/ $U$ ratios $<0.03)$, which is very similar (within error) to our metamorphic age.

In the Ceará Central Domain, Gomes (2013) reported $\mathrm{U}-\mathrm{Pb}$ (LA-ICPMS) zircon age of 2046 $12 \mathrm{Ma}$ for a leucosome in a metaplutonic migmatite rock of the São José do Macaoca Complex, with crystallization age of $2132 \pm 34 \mathrm{Ma}$.

The record of the Transamazonian/Eburnean high-grade metamorphism in the Troia Massif is also evidenced by the $\mathrm{U}-\mathrm{Pb}$ SHRIMP age of $2084 \pm 14 \mathrm{Ma}$ on metamorphic zircon rims 
TABLE - 1 U-Pb LA-ICPMS zircon data

\begin{tabular}{|c|c|c|c|c|c|c|c|c|c|c|c|c|c|c|c|c|c|}
\hline spot & f206(\%) & Th/U & ${ }^{206} \mathrm{~Pb} / 204 \mathrm{~Pb}$ & ${ }^{207} \mathrm{~Pb} / 206 \mathrm{~Pb}$ & $\pm 1 \sigma \quad(\%)$ & ${ }^{207} \mathrm{~Pb} /{ }^{235} \mathrm{U}$ & $\pm 1 \sigma(\%)$ & ${ }^{206} \mathrm{~Pb} /{ }^{238} \mathrm{U}$ & $\pm 1 \sigma(\%)$ & Rho & ${ }^{207} \mathrm{~Pb} /{ }^{206} \mathrm{~Pb}$ & $\pm 1 \sigma(\mathrm{Ma})$ & ${ }^{207} \mathrm{~Pb} /{ }^{235} \mathrm{U}$ & $\pm 1 \sigma(\mathrm{Ma})$ & ${ }^{206} \mathrm{~Pb} / 238 \mathrm{U}$ & $\pm 1 \sigma(\mathrm{Ma})$ & Conc. (\%) \\
\hline \multicolumn{18}{|l|}{ Zircon rims } \\
\hline $030-Z 22$ & 0.012 & 0.0014 & 123874 & 0.1242 & 0.3415 & 5.7056 & 1.1427 & 0.3331 & 1.0904 & 0.9512 & 2018 & 6 & 1932 & 10 & 1853 & 18 & 92 \\
\hline 010-Z08 & 0.005 & 0.0026 & 310749 & 0.1278 & 0.2911 & 6.0772 & 0.8947 & 0.3449 & 0.8461 & 0.9389 & 2068 & 5 & 1987 & 8 & 1910 & 14 & 92 \\
\hline 066-Z46 & 0.016 & 0.0017 & 96744 & 0.1256 & 0.4341 & 5.9226 & 1.5586 & 0.3419 & 1.4969 & 0.9591 & 2038 & 8 & 1965 & 14 & 1896 & 25 & 93 \\
\hline 080-Z58 & 0.028 & 0.0035 & 54488 & 0.1211 & 0.4980 & 5.6189 & 2.0021 & 0.3364 & 1.9392 & 0.9680 & 1973 & 9 & 1919 & 17 & 1869 & 31 & 95 \\
\hline 019-Z13 & 0.004 & 0.0004 & 354462 & 0.1259 & 0.3142 & 6.1181 & 1.1493 & 0.3526 & 1.1055 & 0.9595 & 2041 & 6 & 1993 & 10 & 1947 & 19 & 95 \\
\hline 089-Z65 & 0.008 & 0.0010 & 187490 & 0.1250 & 0.3767 & 6.1165 & 1.3881 & 0.3549 & 1.3360 & 0.9609 & 2029 & 7 & 1993 & 12 & 1958 & 23 & 97 \\
\hline $018-Z 12-2$ & 0.009 & 0.0014 & 167303 & 0.1290 & 0.2507 & 6.6408 & 1.0209 & 0.3734 & 0.9896 & 0.9671 & 2084 & 4 & 2065 & 9 & 2045 & 17 & 98 \\
\hline 023-Z15 & 0.005 & 0.0014 & 308005 & 0.1262 & 0.3195 & 6.4583 & 1.0288 & 0.3712 & 0.9780 & 0.9462 & 2046 & 6 & 2040 & 9 & 2035 & 17 & 99 \\
\hline \multicolumn{18}{|c|}{ Excluded zircons (possible mixture of rims and cores) } \\
\hline 006-Z04 & 0.007 & 0.0116 & 221782 & 0.1330 & 0.3100 & 6.5274 & 0.7857 & 0.3560 & 0.7220 & 0.9042 & 2138 & 5 & 2050 & 7 & 1963 & 12 & 92 \\
\hline 078-Z56 & 0.011 & 0.0013 & 137294 & 0.1355 & 0.3397 & 7.0467 & 1.3677 & 0.3772 & 1.3249 & 0.9674 & 2171 & 6 & 2117 & 12 & 2063 & 23 & 95 \\
\hline 063-43B & 0.015 & 0.0015 & 96430 & 0.1304 & 0.4742 & 6.9955 & 1.9047 & 0.3890 & 1.8447 & 0.9679 & 2104 & 8 & 2111 & 17 & 2118 & 33 & 101 \\
\hline 075-Z53 & 0.007 & 0.0042 & 201787 & 0.1321 & 0.3108 & 7.3748 & 1.8219 & 0.4048 & 1.7952 & 0.9852 & 2127 & 5 & 2158 & 16 & 2191 & 33 & 103 \\
\hline 084-Z60 & 0.064 & 0.3082 & 23302 & 0.1260 & 0.9342 & 6.8695 & 2.7488 & 0.3956 & 2.5852 & 0.9398 & 2042 & 17 & 2095 & 24 & 2149 & 47 & 105 \\
\hline \multicolumn{18}{|c|}{ Zircon cores } \\
\hline 083-Z59 & 0.035 & 0.3146 & 43183 & 0.1317 & 0.4903 & 6.4461 & 1.7782 & 0.3549 & 1.7093 & 0.9602 & 2121 & 9 & 2039 & 16 & 1958 & 29 & 92 \\
\hline $060-Z 43 \mathrm{~N}$ & 0.004 & 0.2180 & 420696 & 0.1330 & 0.4986 & 7.0992 & 1.3567 & 0.3872 & 1.2618 & 0.9264 & 2137 & 9 & 2124 & 12 & 2110 & 23 & 99 \\
\hline 036-Z25 & 0.015 & 0.2496 & 104303 & 0.1331 & 0.3162 & 6.4383 & 1.0492 & 0.3508 & 1.0004 & 0.9497 & 2139 & 6 & 2038 & 9 & 1938 & 17 & 91 \\
\hline 053-Z36N & 0.009 & 0.2697 & 166517 & 0.1335 & 0.3497 & 6.6944 & 1.0760 & 0.3636 & 1.0176 & 0.9413 & 2145 & 6 & 2072 & 10 & 1999 & 17 & 93 \\
\hline $049-Z 35 \mathrm{~N}$ & 0.017 & 0.1985 & 88729 & 0.1342 & 0.3289 & 7.0342 & 1.3506 & 0.3802 & 1.3100 & 0.9687 & 2153 & 6 & 2116 & 12 & 2077 & 23 & 96 \\
\hline 039-Z28 & 0.005 & 0.3171 & 296503 & 0.1352 & 0.2549 & 7.1848 & 0.8989 & 0.3855 & 0.8620 & 0.9543 & 2166 & 4 & 2135 & 8 & 2102 & 15 & 97 \\
\hline 085-Z61 & 0.023 & 0.2862 & 64441 & 0.1368 & 0.4505 & 7.7408 & 1.8302 & 0.4105 & 1.7739 & 0.9686 & 2187 & 8 & 2201 & 16 & 2217 & 33 & 101 \\
\hline 027-Z19 & 0.010 & 0.2547 & 155767 & 0.1371 & 0.3206 & 7.5499 & 0.9450 & 0.3993 & 0.8889 & 0.9341 & 2191 & 6 & 2179 & 8 & 2166 & 16 & 99 \\
\hline 067-Z47 & 0.002 & 0.2146 & 764030 & 0.1374 & 0.3437 & 7.0074 & 1.2447 & 0.3700 & 1.1963 & 0.9590 & 2194 & 6 & 2112 & 11 & 2029 & 21 & 92 \\
\hline 034-Z23 & 0.010 & 0.4100 & 151374 & 0.1375 & 0.3090 & 7.1005 & 2.7563 & 0.3745 & 2.7390 & 0.9937 & 2196 & 5 & 2124 & 25 & 2050 & 48 & 93 \\
\hline 059-Z42 & 0.022 & 0.3912 & 67595 & 0.1377 & 0.5753 & 6.8918 & 1.4102 & 0.3630 & 1.2876 & 0.9087 & 2199 & 10 & 2098 & 13 & 1996 & 22 & 91 \\
\hline 058-Z41 & 0.026 & 0.2024 & 56827 & 0.1384 & 0.4900 & 7.7812 & 1.7643 & 0.4077 & 1.6949 & 0.9596 & 2208 & 9 & 2206 & 16 & 2204 & 32 & 100 \\
\hline 073-Z51 & 0.031 & 0.7060 & 49303 & 0.1407 & 0.7024 & 7.2996 & 2.7693 & 0.3763 & 2.6787 & 0.9670 & 2236 & 12 & 2149 & 25 & 2059 & 47 & 92 \\
\hline 040-Z29 & 0.006 & 0.2382 & 259816 & 0.1415 & 0.3482 & 8.0406 & 1.1435 & 0.4122 & 1.0892 & 0.9493 & 2245 & 6 & 2236 & 10 & 2225 & 20 & 99 \\
\hline 069-Z49 & 0.032 & 0.2057 & 46116 & 0.1425 & 0.3896 & 7.9491 & 1.5299 & 0.4047 & 1.4794 & 0.9660 & 2257 & 7 & 2225 & 14 & 2191 & 27 & 97 \\
\hline 044-Z31N & 0.036 & 0.9920 & 38968 & 0.1426 & 1.1045 & 9.0855 & 2.5390 & 0.4622 & 2.2861 & 0.8989 & 2258 & 19 & 2347 & 23 & 2449 & 47 & 108 \\
\hline 026-Z18 & 0.006 & 0.1429 & 241256 & 0.1480 & 0.2972 & 8.2877 & 0.9906 & 0.4060 & 0.9449 & 0.9496 & 2323 & 5 & 2263 & 9 & 2197 & 18 & 95 \\
\hline $043-Z 30$ & 0.008 & 0.0255 & 187654 & 0.1494 & 0.3443 & 8.2310 & 1.5099 & 0.3995 & 1.4701 & 0.9729 & 2339 & 6 & 2257 & 14 & 2167 & 27 & 93 \\
\hline 025-Z17 & 0.009 & 0.3184 & 170940 & 0.1505 & 0.4338 & 8.4090 & 1.1126 & 0.4053 & 1.0245 & 0.9144 & 2351 & 7 & 2276 & 10 & 2194 & 19 & 93 \\
\hline $045-\mathrm{Z} 32 \mathrm{~N}$ & 0.069 & 0.4380 & 20998 & 0.1514 & 0.4574 & 8.8974 & 1.6008 & 0.4261 & 1.5340 & 0.9570 & 2362 & 8 & 2328 & 15 & 2288 & 30 & 97 \\
\hline
\end{tabular}




\begin{tabular}{|c|c|c|c|c|c|c|c|c|c|c|c|c|c|c|c|c|c|}
\hline 079-Z57 & 0.023 & 0.5859 & 62757 & 0.1523 & 0.8891 & 8.5620 & 2.3438 & 0.4077 & 2.1686 & 0.9240 & 2372 & 15 & 2293 & 21 & 2204 & 40 & 93 \\
\hline 003-Z01 & 0.020 & 0.3149 & 70374 & 0.1529 & 0.3632 & 9.3687 & 1.2671 & 0.4443 & 1.2139 & 0.9558 & 2379 & 6 & 2375 & 12 & 2370 & 24 & 100 \\
\hline 057-Z40 & 0.021 & 0.1344 & 67325 & 0.1559 & 0.4317 & 9.6725 & 1.1703 & 0.4501 & 1.0877 & 0.9244 & 2411 & 7 & 2404 & 11 & 2396 & 22 & 99 \\
\hline 086-Z62 & 0.016 & 0.2555 & 88001 & 0.1579 & 0.3463 & 9.7256 & 1.1736 & 0.4466 & 1.1213 & 0.9526 & 2434 & 6 & 2409 & 11 & 2380 & 22 & 98 \\
\hline 087-Z63 & 0.003 & 0.3477 & 422786 & 0.1583 & 0.2968 & 9.8877 & 0.9550 & 0.4531 & 0.9077 & 0.9453 & 2437 & 5 & 2424 & 9 & 2409 & 18 & 99 \\
\hline 004-Z02 & 0.019 & 0.2045 & 75826 & 0.1598 & 0.3773 & 9.0704 & 1.3674 & 0.4118 & 1.3143 & 0.9595 & 2453 & 6 & 2345 & 13 & 2223 & 25 & 91 \\
\hline 068-Z48 & 0.013 & 0.2671 & 110207 & 0.1601 & 0.4093 & 9.7776 & 3.9031 & 0.4429 & 3.8816 & 0.9945 & 2457 & 7 & 2414 & 36 & 2364 & 77 & 96 \\
\hline 017-Z12-1 & 0.021 & 0.4659 & 68700 & 0.1653 & 0.3520 & 10.6809 & 1.2428 & 0.4688 & 1.1919 & 0.9568 & 2510 & 6 & 2496 & 12 & 2478 & 25 & 99 \\
\hline 088-Z64 & 0.065 & 0.3385 & 21958 & 0.1654 & 0.9177 & 10.5362 & 2.5891 & 0.4621 & 2.4210 & 0.9342 & 2511 & 15 & 2483 & 24 & 2449 & 49 & 98 \\
\hline
\end{tabular}

Excluded zircons (concordance $<90 \%$ )

\begin{tabular}{|c|c|c|c|c|c|c|c|c|c|c|c|c|c|c|c|c|c|}
\hline 037-Z26 & 0.128 & 0.2555 & 13937 & 0.1532 & 1.0913 & 1.8159 & 27.6479 & 0.0860 & 27.6263 & 0.9992 & 2382 & 19 & 1051 & 181 & 532 & 141 & 22 \\
\hline 048-Z34 & 0.180 & 0.0297 & 9512 & 0.1462 & 1.4303 & 3.1914 & 9.6056 & 0.1583 & 9.4985 & 0.9889 & 2302 & 25 & 1455 & 74 & 947 & 84 & 41 \\
\hline 015-Z10 & 0.106 & 0.1016 & 16345 & 0.1260 & 0.2570 & 2.4918 & 2.2586 & 0.1434 & 2.2439 & 0.9936 & 2044 & 5 & 1270 & 16 & 864 & 18 & 42 \\
\hline 009-Z07 & 0.020 & 0.3954 & 82421 & 0.1405 & 0.3426 & 3.6030 & 6.1743 & 0.1860 & 6.1648 & 0.9985 & 2233 & 6 & 1550 & 49 & 1100 & 62 & 49 \\
\hline 070-Z50 & 0.055 & 0.0065 & 30732 & 0.1272 & 0.4274 & 3.2897 & 2.5076 & 0.1875 & 2.4709 & 0.9853 & 2060 & 8 & 1479 & 20 & 1108 & 25 & 54 \\
\hline $020-Z 14$ & 0.124 & 0.1889 & 13407 & 0.1455 & 1.5271 & 4.2928 & 5.9599 & 0.2140 & 5.7609 & 0.9665 & 2293 & 26 & 1692 & 49 & 1250 & 65 & 55 \\
\hline 014-Z09 & 0.035 & 0.0022 & 47638 & 0.1260 & 0.3173 & 3.3131 & 4.9643 & 0.1907 & 4.9541 & 0.9980 & 2043 & 6 & 1484 & 39 & 1125 & 51 & 55 \\
\hline 047-Z33 & 0.035 & 0.0014 & 47438 & 0.1441 & 2.4501 & 4.4559 & 6.0159 & 0.2242 & 5.4943 & 0.9131 & 2277 & 42 & 1723 & 50 & 1304 & 65 & 57 \\
\hline 016-Z11 & 1.940 & 0.0093 & 840 & 0.1583 & 4.1183 & 5.2909 & 6.2872 & 0.2424 & 4.7506 & 0.7902 & 2438 & 68 & 1867 & 52 & 1399 & 59 & 57 \\
\hline 054-Z37 & 0.069 & 0.2032 & 23808 & 0.1376 & 0.4971 & 4.2025 & 2.8251 & 0.2215 & 2.7810 & 0.9843 & 2197 & 9 & 1675 & 23 & 1290 & 33 & 59 \\
\hline 074-Z52 & 0.149 & 0.0041 & 11086 & 0.1287 & 0.2522 & 3.9239 & 1.2703 & 0.2211 & 1.2450 & 0.9794 & 2080 & 4 & 1619 & 10 & 1288 & 15 & 62 \\
\hline $035-\mathrm{Z} 24$ & 0.016 & 0.0009 & 105269 & 0.1222 & 0.2660 & 3.6042 & 2.8873 & 0.2139 & 2.8750 & 0.9958 & 1989 & 5 & 1550 & 23 & 1250 & 33 & 63 \\
\hline 076-Z54 & 0.026 & 0.2012 & 60801 & 0.1573 & 0.3497 & 5.8889 & 2.6021 & 0.2716 & 2.5785 & 0.9909 & 2427 & 6 & 1960 & 23 & 1549 & 35 & 64 \\
\hline 024-Z16 & 0.011 & 0.0006 & 142679 & 0.1272 & 0.3934 & 4.1699 & 2.1476 & 0.2377 & 2.1112 & 0.9829 & 2060 & 7 & 1668 & 18 & 1375 & 26 & 67 \\
\hline 077-Z55 & 0.019 & 0.0027 & 82385 & 0.1309 & 0.3697 & 4.9577 & 1.3947 & 0.2747 & 1.3448 & 0.9628 & 2110 & 6 & 1812 & 12 & 1565 & 19 & 74 \\
\hline 038-Z27 & 0.008 & 0.4042 & 195827 & 0.1435 & 0.2546 & 6.2445 & 1.6569 & 0.3156 & 1.6372 & 0.9880 & 2270 & 4 & 2011 & 15 & 1768 & 25 & 78 \\
\hline 064-Z44 & 0.010 & 0.1348 & 159621 & 0.1321 & 0.4629 & 5.6819 & 1.5176 & 0.3118 & 1.4453 & 0.9505 & 2127 & 8 & 1929 & 13 & 1750 & 22 & 82 \\
\hline 005-Z03 & 0.004 & 0.1219 & 329827 & 0.2126 & 0.4240 & 13.4329 & 0.9270 & 0.4581 & 0.8243 & 0.8749 & 2926 & 7 & 2711 & 9 & 2431 & 17 & 83 \\
\hline 007-Z05 & 0.006 & 0.3370 & 240460 & 0.1504 & 0.3078 & 7.3626 & 1.6000 & 0.3550 & 1.5701 & 0.9809 & 2351 & 5 & 2156 & 14 & 1959 & 27 & 83 \\
\hline 046-Z32B & 0.013 & 0.0015 & 120252 & 0.1255 & 0.3700 & 5.3152 & 1.3864 & 0.3073 & 1.3361 & 0.9622 & 2035 & 7 & 1871 & 12 & 1727 & 20 & 85 \\
\hline $029-Z 21$ & 0.005 & 0.2381 & 325416 & 0.1546 & 0.2991 & 8.0397 & 1.1905 & 0.3772 & 1.1523 & 0.9662 & 2397 & 5 & 2235 & 11 & 2063 & 20 & 86 \\
\hline $055-Z 38 B$ & 0.014 & 0.0130 & 115703 & 0.1203 & 0.3035 & 5.0490 & 1.1759 & 0.3043 & 1.1361 & 0.9642 & 1961 & 5 & 1828 & 10 & 1713 & 17 & 87 \\
\hline 065-Z45 & 0.011 & 0.2350 & 143605 & 0.1427 & 0.4171 & 7.1111 & 1.4494 & 0.3614 & 1.3880 & 0.9560 & 2260 & 7 & 2125 & 13 & 1989 & 24 & 88 \\
\hline $008-Z 06$ & 0.004 & 0.0013 & 369261 & 0.1282 & 0.3249 & 5.8078 & 0.8105 & 0.3285 & 0.7425 & 0.9019 & 2074 & 6 & 1948 & 7 & 1831 & 12 & 88 \\
\hline $028-\mathrm{Z} 20$ & 0.016 & 0.0018 & 97869 & 0.1221 & 0.2961 & 5.3094 & 1.0681 & 0.3153 & 1.0262 & 0.9578 & 1987 & 5 & 1870 & 9 & 1767 & 16 & 89 \\
\hline 056-Z39 & 0.048 & 0.2248 & 31337 & 0.1507 & 0.8852 & 7.9832 & 2.9611 & 0.3843 & 2.8257 & 0.9538 & 2354 & 15 & 2229 & 27 & 2096 & 51 & 89 \\
\hline $050-Z 35 B$ & 0.016 & 0.0011 & 97955 & 0.1218 & 0.3784 & 5.3140 & 1.8837 & 0.3164 & 1.8453 & 0.9793 & 1983 & 7 & 1871 & 16 & 1772 & 29 & 89 \\
\hline
\end{tabular}




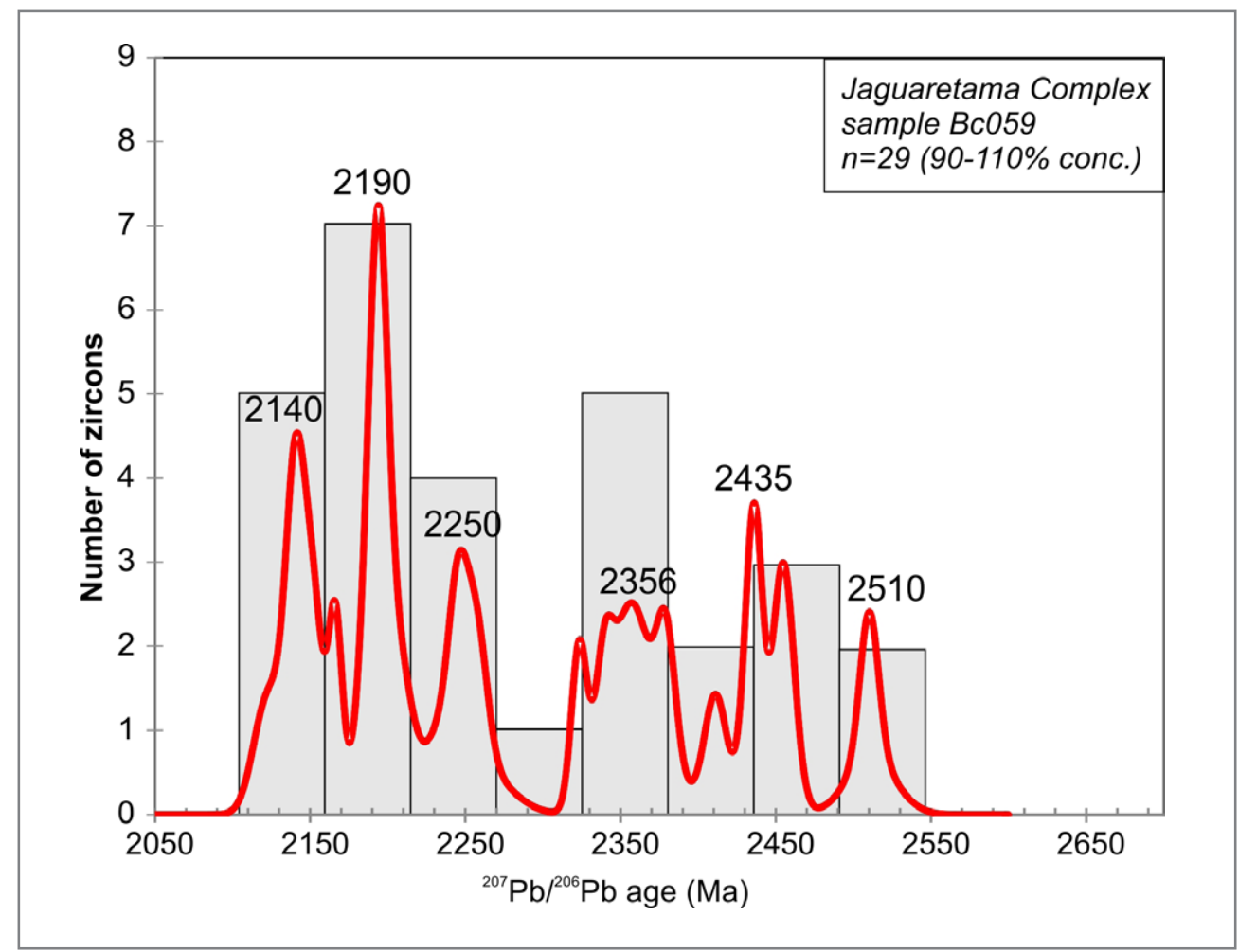

FIGURE 5 - Frequency histograms and probability plot of ${ }^{207} \mathrm{~Pb} /{ }^{206} \mathrm{~Pb}$ detrital zircon ages $(90-110 \%$ conc.).

of hornblende-biotite tonalite from Cruzeta Complex (CearáCentral Domain) with crystallization age of $3270 \pm 5 \mathrm{Ma}$ (Silva et al. 2002). Also, in the Troia Massif, the Archean orthogneiss from the Pedra Branca Unit dated at $2698 \pm 8 \mathrm{Ma}(\mathrm{U}-\mathrm{Pb}$ zircon SHRIMP) presented two zircons with low $\mathrm{Th} / \mathrm{U}$ values, which yielded slightly discordant ${ }^{207} \mathrm{~Pb} / 206 \mathrm{~Pb}$ ages of $2057 \pm 8 \mathrm{Ma}$ and $1721 \pm 14$ Ma respectively (Ganade et al. 2017).

In the West African counterpart, eclogites of the Nyong Complex, in southern Cameroon, provide evidence for a Paleoproterozoic continental collision along the northwestern border of the Congo Craton (Loose and Schenk 2017). The age of the eclogitic metamorphism has been constrained by $\mathrm{U}-\mathrm{Pb}$ SHRIMP dating of zircon at $2093 \pm 45 \mathrm{Ma}$ and is interpreted as the product of a collisional event between the Congo and São Francisco Cratons (Loose and Schenk 2017). The lenses of eclogites (metabasites) are interpreted as relicts of ocean floor basalts (Loose and Schenk 2017). In the West Africa Craton, according to McFarlene (2018), the timing of metamorphism and terrane exhumation in the Ghana region are constrained by in situ monazite U-Pb SHRIMP ages of $2073 \pm 2 \mathrm{Ma}$ and $2074 \pm 3 \mathrm{Ma}$. This is also similar to the metamorphic ages reported at the northeast of the São Francisco Craton, evidenced by SHRIMP U-Pb zircon ages of the Caldeirão quartzite, which yielded an age of $2076 \pm 10 \mathrm{Ma}$ for the zircon overgrowths, with low Th/U ratios $(<0.1)$ (Oliveira and Melo 2002). Furthermore, in the northeast of the São Francisco craton, deformation and high-grade metamorphism also affected the basement rocks of the Neoarchean Caraíba Complex, with crystallization age of $2574 \pm 6$ Ma obtained for the igneous zircon cores, and an age of $2074 \pm 14$ Ma calculated for the metamorphic rims (Oliveira et al. 2010).
The Table 2 present the compilation for the record of Paleoproterozoic high-grade metamorphism discussed in the text, which are all strongly correlated in time with the metamorphic age of $2046 \pm 6 \mathrm{Ma}$, obtained in this work. However, this age of metamorphism is slightly older when compared with two metamorphic zircon ages of $1971 \pm 40 \mathrm{Ma}$ and $1997 \pm 20$ Ma obtained from a high-grade metamorphic supracrustal sequence of the southern São Francisco Craton (Teixeira et al. 2017). So far, the age of ca. 1.99-1.97 Ga for the high-grade metamorphism in the southern São Francisco Craton, differs from the other compiled data from the northern Borborema Province and surrounding terranes, with the age interval of ca. 2.09-2.04 Ga (Table 2). This may reflect a diachronic nature of the collisional orogen, in which, the docking of continental blocks and arc sequences during a supercontinent formation, may vary slightly in time (e.g. Teixeira et al. 2017; Zhao et al. 2002). In addition, similar metamorphic ages of 2015-1960 Ma (U-Pb in monazite) have been found in the basement rocks of the southern Araçuaí Belt (Cutts et al. 2018).

Finally, in terms of metallogenetic implications, the metasedimentary sequence of the Jaguaretama Complex, commonly presents metamorphic graphite crystals (Fig. 3F), which is typical of many others Paleoproterozoic synorogenic sedimentary basins, such as those described in the North China and São Francisco cratons (e.g. Yang et al. 2014; Teixeira et al. 2017). The graphite crystals (or flakes) were generated through the conversion of organic matter present in ancient sediments, subjected to granulite-facies conditions (e.g. Yang et al. 2014; Teixeira et al. 2017). Therefore, the age of metamorphism at $2046 \pm 6 \mathrm{Ma}$ acquired in this work, 
Table 2 -Paleoproterozoic high-grade metamorphic records at the Borborema Province and surrounding cratonic domains.

\begin{tabular}{|c|c|c|c|c|}
\hline Location & Unit & Methodology and Rock type & Age (Ma) & Reference \\
\hline Congo craton & Nyong complex & U-Pb SHRIMP dating of zircon from eclogite & $2093 \pm 45$ & Loose \& Schenk (2017) \\
\hline Northern Borborema & Cruzeta complex & $\begin{array}{l}\text { U-Pb SHRIMP age found in metamorphic zircon rims from } \\
\text { metatonalite }\end{array}$ & $2084 \pm 14$ & Silva et al. (2002) \\
\hline São Francisco craton & Caldeirão quartzite belt & $\begin{array}{l}\text { U-Pb SHRIMP age found in metamorphic zircon rims from } \\
\text { quartzite }\end{array}$ & $2076 \pm 10$ & Oliveira et al. (2002) \\
\hline West Africa craton & Sefwi Greenstone belt & U-Pb SHRIMP age in monazite from paragneiss & $2074 \pm 3$ & McFarlene (2018) \\
\hline São Francisco craton & Caraiba complex & $\begin{array}{l}\text { U-Pb SHRIMP age found in metamorphic zircon rims from } \\
\text { orthogneiss }\end{array}$ & $2074 \pm 14$ & Oliveira et al. (2010) \\
\hline West Africa craton & Sefwi Greenstone belt & U-Pb SHRIMP age in monazite from paragneiss & $2073 \pm 2$ & McFarlene (2018) \\
\hline Northern Borborema & Canindé complex & $\begin{array}{l}\text { U-Pb LA-ICPMS age in metamorphic zircons from parag- } \\
\text { neiss }\end{array}$ & $2071 \pm 18$ & Costa \& Palheta (2017) \\
\hline Northern Borborema & Canindé complex & U-Pb LA-ICPMS age for S-type granite & $2070 \pm 19$ & Garcia et al (2014) \\
\hline Northern Borborema & Cruzeta complex & $\begin{array}{l}\text { U-Pb SHRIMP age found in metamorphic zircon rims from } \\
\text { orthogneiss }\end{array}$ & $2057 \pm 8$ & Ganade et al. (2017) \\
\hline Transversal Borborema & Vertentes complex & $\begin{array}{l}\text { U-Pb LA-ICPMS zircon age for a mafic layer of banded } \\
\text { orthogneiss }\end{array}$ & $2048 \pm 22$ & Neves et al. (2015) \\
\hline Northern Borborema & Canindé complex & $\begin{array}{l}\text { U-Pb LA-ICPMS zircon age for a leucosome vein in orthog- } \\
\text { neiss }\end{array}$ & $2046 \pm 12$ & Gomes (2013) \\
\hline Northern Borborema & Jaguaretama complex & $\begin{array}{l}\text { U-Pb LA-ICPMS age in metamorphic zircon rims from } \\
\text { paragneiss }\end{array}$ & $2045 \pm 6$ & This work \\
\hline Central Borborema & East Pernambuco belt & $\begin{array}{l}\text { U-Pb LA-ICPMS zircon age for a mafic layer of banded } \\
\text { orthogneiss }\end{array}$ & $2044 \pm 5$ & Neves et al. (2006) \\
\hline Central Borborema & East Pernambuco belt & U-Pb LA-ICPMS zircon age for a leucosome of paragneiss & $2041 \pm 15$ & Neves et al. (2006) \\
\hline Transversal Borborema & Alto Moxoto terrain & $\begin{array}{l}\text { U-Pb SHRIMP age found in metamorphic zircon rims from } \\
\text { orthogneiss }\end{array}$ & $2012 \pm 17$ & Santos et al. (2013) \\
\hline São Francisco craton & Minas Orogen & U-Pb LA-ICPMS zircon age for a graphitic paragneiss & $1997 \pm 20$ & Teixeira et al. (2017) \\
\hline São Francisco craton & Minas Orogen & U-Pb LA-ICPMS zircon age for a sill-grt-quartzite & $1971 \pm 40$ & Teixeira et al. (2017) \\
\hline Araçuaí belt & Acaiaca complex & U-Pb-LA-SF-ICPMS monazite age for graulites & $1964 \pm 13$ & Cutts et al. (2018) \\
\hline
\end{tabular}


may be inferred also as the age of graphite mineralization in the Jaguaretama Complex and correlated domains of the Ceará Central Domain (e.g. Canindé Complex). In the northern Borborema Province, studies on graphite deposits of the Ceara Central Domain resulted in $\delta^{13} \mathrm{C}$ values of -26.72 to $-23.52 \%$ in the disseminated ore and -27.03 to $-20.83 \%$ in massive ore (Fragomeni and Pereira, 2013). These results are similar to carbon isotopes from graphite samples from the metasedimentary rocks of the Serra das Pipocas greenstone belt, in the Troia Massif, which yielded $\delta^{13} \mathrm{C}$ values of -27.1 and $-22.7 \%$, indicating a biogenic composition (Costa et al. 2019).

\section{Conclusion}

The $\mathrm{U}-\mathrm{Pb}$ zircon ages for the studied metasedimentary rock from Jaguaretama Complex, indicate that the precursor basin was essentially fed with Rhyacian and Siderian zircons, with only two Archean grains showing ${ }^{207} \mathrm{~Pb} /{ }^{206} \mathrm{~Pb}$ ages of ca. $2.51 \mathrm{Ga}$. Most of the detrital zircons with ages between ca. 2.1 and $2.3 \mathrm{Ga}$ were probably derived from sources of igneous rocks emplaced during the pre-collisional stage of the Transamazonian/Eburnean orogeny. The ${ }^{207} \mathrm{~Pb} /{ }^{206} \mathrm{~Pb}$ age of $2045 \pm 9$ Ma for the most concordant (conc. 99\%) metamorphic zircon overgrowth is interpreted here as the age of high-grade metamorphism. This is similar in age to many other records of Paleoproterozoic high-grade metamorphism in the Borborema Province and surrounding cratonic domains (e.g. São Francisco and West Africa cratons). This age also represents the minimum depositional age of the protolith, whilst, the ${ }^{207} \mathrm{~Pb} /{ }^{206} \mathrm{~Pb}$ age of $2137 \pm 9$ for the youngest concordant zircon represents the maximum depositional age. Therefore, the depositional age of the studied supracrustal rocks may be bracketed between ca. 2137 and $2046 \mathrm{Ma}$. The protolith of the metasedimentary sequence of the Jaguaretama Complex probably deposited shortly before and/or during the collisional stage of the Transamazonian/Eburnean orogeny. We suggest that this age of ca. $2046 \mathrm{Ma}$ for the metamorphism, may also be inferred as the age of graphite mineralization in the Paleoproterozoic high-grade supracrustal sequences of the northern Borborema Province (e.g., Jaguaretama and Canindé complexes).

\section{Acknowledgement}

This paper is a contribution of Geological Survey of Brazil (CPRM) through the mapping project of the Bonhu 1:100.000 topographic sheet, which was funded by the Brazilian Federal Government. We wish to thank Dr. Bert De Waele, Prof. Jean Michel Lafon, and an anonymous reviewer, who provided valuable suggestions to improve this manuscript.

\section{References}

Abouchami W., Boher M., Michard A., Albarede F. 1990. A major 2.1 event of mafic magmatism in West Africa: an early stage of crustal accretion. Journal of Geophysical Research, 95(B11), 17605-17629. https://doi. org/10.1029/JB095iB11p17605

Almeida F., Hasui Y., Brito Neves B., Fuck R. 1981. Brazilian structural provinces: an introduction. Earth-Sciences Reviews, 17 (1-2), 1-29. https://doi.org/10.1016/0012-8252(81)90003-9

Ancelmi M.F. 2016. Geocronologia e Geoquímica das Rochas Arqueanas do Complexo Granjeiro, Província Borborema. PhD Thesis, Instituto de Geociências, Universidade Estadual de Campinas, Campinas-SP. 159 p.

Baratoux L., Metelka V., Naba S., Jessel M., Grégoire M., Ganne, J. 2011. Juvenile Paleoproterozoic crust evolution during the Eburnean orogeny $\sim 2.2-2.0 \mathrm{Ga}$, western Burkina Faso. Precambrian Research, 191(1-2), 18-45. https://doi.org/10.1016/j.precamres.2011.08.010

Block S., Jessell M., Aillères L., Baratoux L., Bruguier O., Zeh A., Bosch D. C. 2016. Lower crust exhumation during Paleoproterozoic Eburnean orogeny, NW Ghana, West African Craton: interplay of coeval contractional deformation and extensional gravitational collapse. Precambrian Research, 274 , 82-109. https://doi.org/10.1016/j. precamres.2015.10.014

Brito Neves B.B., Santos E.J., Van Schmus W.R. 2000. Tectonic History of the Borborema Province, Northeastern Brazil. In: Cordani U.G., Milani E.J., Thomaz A., Campos D.A. Tectonic evolution of South America. Rio de Janeiro, CPRM. p. 151-182.

Bühn B., Pimentel M., Matteini M., Dantas E. 2009. High spatial resolution analysis of $\mathrm{Pb}$ and $\mathrm{U}$ isotopes for geochronology by laser ablation multi-collector inductively coupled plasma mass apectrometry LAMC-IC-MS. Anais da Academia Brasileira de Ciências, 81, 99-114. http://dx.doi.org/10.1590/S0001-37652009000100011

Calado B.O. 2017. Geologia e recursos minerais da folha Bonhu: SB.24X-A-V: estado do Ceará. Escala 1:100.000. Programa Geologia do Brasil. Fortaleza, CPRM. Available on line at: http://rigeo.cprm.gov.br/ jspui/handle/doc/19023 / (acessed on: 22 January 2019)

Cavalcante J., Vasconcelos A., Medeiros M., Gomes I., Gomes F., Cavalcante S., Benevides H. 2003. Mapa geológico do estado do Ceará. Escala 1:500.000. Fortaleza, CPRM. Avaiable on line at: http:// rigeo.cprm.gov.br/jspui/handle/doc/2355 / (acessed on: 22 January 2019)

Cordani U., Sato K. 1999. Crustal evolution of the South America Platform based on $\mathrm{Nd}$ isotopic systematics of igneous rocks. Episodes, 22, (3), 167-173. https://doi.org/10.18814/epiiugs/1999/v22i3/003

Costa F. 2018. Geologia e metalogênese do ouro do greenstone belt da Serra das Pipocas, Maciço de Troia, Província Borborema, NE-Brasil. PhD Thesis, Instituto de Geociências, Universidade Federal do Pará, Belém, Pará, 226 p. Available on line at: http://repositorio.ufpa.br/ jspui/handle/2011/10497

Costa F., Palheta E. 2017. Geologia e recursos minerais das folhas Quixadá (SB.24-V-B-IV) e Itapiúna (SB.24-X-A-IV). Escala 1:100.000. Fortaleza, CPRM. Available on line at: http://rigeo.cprm.gov.br/jspui/ handle/doc/19029/ (accessed on 22 January 2019)

Costa F., Klein E., Corrêa-Lima R., Naleto J. 2016. Geology, geochronology and gold metallogenesis of the Serra das Pipocas granite-greenstone terrane. In: Congresso Brasileiro de Geologia, 48, 9278.

Costa F., Klein E., Harris C., Roopnarain S. 2019. Fluid inclusion and stable isotope $\mathrm{O}, \mathrm{H}, \mathrm{C}$ constraints on the genesis of the Pedra Branca gold deposit, Troia Massif, Borborema Province, NE Brazil: an example of hypozonal orogenic gold mineralization. Ore Geology Review, 107, 476-500. https://doi.org/10.1016/j.oregeorev.2019.03.007

Costa F., Palheta E., Rodrigues J., Gomes I., Vasconcelos A. 2015 Geochemistry and $\mathrm{U}-\mathrm{Pb}$ zircon ages of plutonic rocks from the Algodões granite-greenstone terrane, Troia Massif, northern Borborema Province, Brazil: implications for Paleoproterozoic subduction-accretion processes. Journal of South American Earth Sciences, 59, 45-68. https://doi.org/10.1016/j.jsames.2015.01.007

Costa F.G., Klein E.L., Lafon J.M., Neto J.M.M., Galarza M.A., Rodrigues J.B., Naleto J.L.C., Lima R.G.C., 2018. Geochemistry and U-Pb$\mathrm{Hf}$ zircon data for plutonic rocks of the Troia Massif, Borborema Province, NE Brazil: Evidence for reworking of Archean and juvenile Paleoproterozoic crust during Rhyacian accretionary and collisional tectonics. Precambrian Research, 311, 167-194. https://doi. org/10.1016/j.precamres.2018.04.008

Costa, F.G., Oliveira, E.P., McNaughton, N., 2011. The Fazenda Gavião granodiorite and associated potassic plutons as evidence for Palaeoproterozoic arc-continent collision in the Rio Itapicuru greenstone belt, Brazil. Journal of South American Earth Sciences, 32 (2), 127-141. https://doi.org/10.1016/j.jsames.2011.04.012

Cutts K., Lana C., Alkimim F., Peres G. 2018. Metamorphic imprints on units of the southern Araçuaí belt, SE Brazil: the history of superimposed Transamazonian and Brasiliano orogenesis. Gondwana Research, 58, 211-234. https://doi.org/10.1016/j.gr.2018.02.016

Dantas E., Van Schmus W., Hackspacher P., Fetter A., Brito Neves B., Cordani U., Williams I. 2004. The 3.4-3.5 Ga São José do Campestre massif, NE Brazil: remmants of the oldest crust in South America. Precambrian Research, 130(1-4), 113-137. https://doi.org/10.1016/j. precamres.2003.11.002

De Kock G., Armstrong R., Siegfried H., Thomas E. 2011. Geochronology of the Birim Supergroup of the West African craton in the Wa-Bolé 
region of west-central Ghana: implications for the stratigraphic framework. Journal of African Earth Sciences, 59, 1-40. https://doi. org/10.1016/j.jafrearsci.2010.08.001

Delor C., Lahondère D., Egal E., Lafon J.M., Cocherie A., Guerrot C., Rossi P., Trufert C., Theveniaut H., Phillips D., Avelar V.G. 2003. Transamazonian crustal growth and reworking as revealed by the 1:500,000-scale geological map of French Guiana (2nd edition). Geologie de la France, 2-3-4, 5-57.

Fetter A. 1999. U/Pb and Sm/Nd Geocronological Constraints on the Crustal Framework and Geologic History of Ceará State, NW Borborema Province, NE Brazil: implications for the Assembly of Gondwana. PhD Thesis, Departament of Geology, Kansas University, Lawrence, Kansas, $164 \mathrm{p}$.

Fetter A., Van Schmus W., Santos T., Neto J., Arthaud M. 2000. U-Pb and Sm-Nd Geochronological constraints on the crustal evolution and basement architecture of Ceará State, NW Borborema Province, NE Brazil: implications for the existence of the Paleoproterozoic Supercontinent "Atlantica". Revista Brasileira de Geociências, 30(1), 102-106. https://doi.org/10.25249/0375-7536.2000301102106

Feybesse J.L., Billa M., Guerrot C., Duguey J.L.L., Milesi J.P., Bouchot V. 2006. The Palaeoproterozoic Ghanaian province: geodynamic model and oro controls, including regional stress modeling. Precambrian Research, 149(3-4) , 149-196. https://doi.org/10.1016/j. precamres.2006.06.003

Fragomeni P., Pereira R. 2013. The graphite mineralization in the Aracoiába-Baturité District CE: geotectonic and metallogenetic implications. Brazilian Journal of Geology, 43, (2), 223-234. https:// doi.org/10.5327/Z2317-48892013000200003

Freimann M. 2014. Geocronologia e petrotrama de quartzo milonitos do duplex transcorrente de Lavras da Mangabeira. MSc Dissertation. Instituto de Geociências, Universidade de São Paulo, São Paulo, 83 p. https://doi.org/10.11606/D.44.2014.tde-26112014-144455

Gasquet D., Barbey P., Adou M., Paquette J.L., 2003. Structure, Sr$\mathrm{Nd}$ isotope geochemistry and zircon $\mathrm{U}-\mathrm{Pb}$ geochronology of the granitoids of the Dabakala area (Côte d'Ivoire): evidence for a 2.3 $\mathrm{Ga}$ crustal growth event in the Palaeoproterozoic of West Africa? Precambrian Research, 127(4), 329-354. https://doi.org/10.1016/ S0301-9268(03)00209-2

Garcia M., Santos T., Amaral W. 2014. Provenance and tectonic setting of neoproterozoic supracrustal rocks from the Ceará Central Domain, Borborema Province NE Brazil: constraints from geochemistry and detrital zircon ages. Internationa Geology Review, 56 (4), 1-20. https:// doi.org/10.1080/00206814.2013.875489

Ganade C.E., Basei M.A.S., Grandjean F.C., Armstrong R., Brito R.S. 2017. Contrasting Archaean $(2.85-2.68 \mathrm{Ga}) \mathrm{TTG}$ from the Tróia Masif (NE-Brazil_and their geodynamic implications for flat to steep subduction transition. Precambrian Research, 297, 1-18. https://doi. org/10.1016/j.precamres.2017.05.007

Gomes E.N. 2013. Protominérios e minérios de manganês de Juá-CE. MSc Dissertation, Instituto de Geociências, Universidade Federal do Ceará, Ceará, 102 p.

Grisolia M., Oliveira E. 2012. Sediment provenance in the Palaeoproterozoic Rio Itapicuru greenstone belt, Brazil, indicates deposition on arc settings within a hidden 2.17-2.25 Ga substrate. Journal of South American Earth Sciences, 38, 89-109. https://doi. org/10.1016/j.jsames.2012.06.004

Hollanda M., Archanjo C., Souza L., Dunyi L., Armstrong R. 2011. Long-lived Paleoproterozoic granitic magmatism in the SeridóJaguaribe domain, Borborema Province-NE Brazil. Journal of South American Earth Sciences, 32(4), 287-300. https://doi.org/10.1016/j. jsames.2011.02.008

Jackson S.E., Pearson N.J., Griffin W.L., Belousova E.A. 2004. The application of laser ablation-inductively coupled plasma-mass spectrometry to in situ U-Pb zircon geochronology. Chemical Geology, 211(1-2), 47-69. https://doi.org/10.1016/j.chemgeo.2004.06.017

Klein E.L., Moura C.A.V. 2008. São Luís craton and Gurupi belt (Brazil): possible links with the West African craton and surrounding PanAfrican belts. In: Pankhurst R.J., Trouw R.A.J., Brito Neves B.B., de Wit M.J. (ed.). West Gondwana: Pre-Cenozoic correlations across the South Atlantic Region. Geological Society, London, Special Publications, 294, 137-151. https://doi.org/10.1144/SP294.8

Klein E.L., Rodrigues J.B., Lopes E.C.S., Soledade G.L. 2012. Diversity of Rhyacian granitoids in the basement of the Neoproterozoic-Early Cambrian Gurupi Belt, northern Brazil: geochemistry, U-Pb zircon geochronology, and $\mathrm{Nd}$ isotope constraints on the Paleoproterozoic magmatic and crustal evolution. Precambrian Research, 220-221, 192-216. https://doi.org/10.1016/j.precamres.2012.08.007

Ledru P., Johan V., Milési J., Tegyey M. 1994. Markers of the last stages of the Paleoproterozoic collision: evidence for a $2 \mathrm{Ga}$ continent involving circum-South Atlantic provinces. Precambrian Research, 69(1-4), 169-191. https://doi.org/10.1016/0301-9268(94)90085-X

Liégeois J.P., Claessens W., Camara D., Klerkx J. 1991. Short-lived Eburnean orogeny in southern Mali. Geology, tectonics, U-Pb and RbSr gechronology. Precambrian Research, 50(1-2), 111-136. https://doi. org/10.1016/0301-9268(91)90050-K

Loose D., Schenk, V. 2017. 2.09 Ga old eclogites in the EburnianTransamazonian orogen of southern Cameroon: significance for Palaeoproterozoic plate tectonics. Precambrian Research, 304, 1-11. https://doi.org/10.1016/j.precamres.2017.10.018

Ludwig K. 2008. Isoplot 3.70 - a geochronological tollkit for Microsoft Excel. Berkeley Geochronology Center, Special Publication, 4.

Martins G., Oliveira E., Lafon J. 2009. The Algodões amphibolite-tonalite gneiss sequence, Borborema Province, NE Brazil: geochemical and geocronological evidence for Paleoproterozoic accretion of oceanic plateu/back-arc basalts and adakitic plutons. Gondwana Research, 15(1), 71-85. https://doi.org/10.1016/j.gr.2008.06.002

McFarlene H. 2018. The geodynamic and tectonic evolution of the Palaeoproterozoic Sefwi Greenstone Belt, West African Craton Ghana. PhD Thesis, Université Paul Sabatier Toulouse III, France, 326 p.

McReath I., Faraco M.T.L. 2006. Paleoproterozoic greenstone-granite belts in Northern Brazil and the former Guyana Shield - West African Craton province. Geologia USP. Série Científica, 5(2), 49-63. https:// doi.org/10.5327/S1519-874X2006000100004

Medeiros V., Nascimento M., Galindo A., Dantas E. 2012. Augen gnaisses riacianos no Domínio Rio Piranhas-Seridó - Província Borborema, Nordeste do Brasil. Geologia USP. Série Científica, 12(2), 3-14. https:// doi.org/10.5327/Z1519-874X2012000200001

Neves S. 2003. Proterozoic history of the Borborema province NE Brazil: correlations with neighboring cratons and Pan-African belts and implications for the evolution of western Gondwana. Tectonics, 22(4), 1031. https://doi.org/10.1029/2001TC001352

Neves S., Bruguier O., Vauchez A., Delphine B., Silva J.M.R., Mariano G. 2006. Timing of crust formation, deposition of supracrustal sequences and Transamazonian and Brasiliano metamorphism in the Eaast Pernambuco belt Borborema Province, NE Brazil: implication for western Gondwana assembly. Precambrian Research, 149(3-4), 197216. https://doi.org/10.1016/j.precamres.2006.06.005

Neves S., Lages G., Brasilino R., Miranda A. 2015. Paleoproterozoic accretionary and collisional processes and the build-up of the Borborema Province NE Brazil: geochronological and geochemical evidence from the Central Domain. Journal of South American Earth Sciences, 58, 165-187. https://doi.org/10.1016/j. jsames.2014.06.009

Oliveira E., Mello E. M. 2002. Reconnaissance U-Pb geochronology of Precambrian quartzites from the Caldeirão belt and their basement, NE São Francisco Craton, Bahia,Brazil: implications for the early evolution of the Paleoproterozoic Itabuna-Salvador-Curaçá orogen. Journal of South American Earth Sciences, 15(3), 349-362. https://doi. org/10.1016/S0895-9811(02)00039-1

Oliveira E., McNaughton N., Armstrong R. 2010. Mesoarchaean to Palaeoproterozoic growth of the northern segment of the ItabunaSalvador-Curaçá orogen, São Francisco craton, Brazil. Geological Society, London, Special Publications, 338, 263-286. https://doi. org/10.1144/SP338.13

Oliveira E.P., Souza Z.S., McNaughton N., Lafon J.M., Costa F.G., Figueiredo A.M. 2011. The Rio Capim volcanic-plutonic-sedimentary belt, São Francisco Craton, Brazil: geological, geochemical and isotopic evidence for oceanic arc accretion during Palaeoproterozoic continental collision. Gondwana Research, 19(3), 735-750. https://doi. org/10.1016/j.gr.2010.06.005

Oliveira R., Medeiros W. 2018. Deep crustal framework of the Borborema Province, NE Brazil, derived from gravity and magnetic data. Precambrian Research, 315, 45-65. https://doi.org/10.1016/j. precamres.2018.07.004

Petersson A., Scherstén A., Gerdes A. 2017. Extensive reworking of Archaean crust within the Birimian terrane in Ghana as revealed by combined zircon $\mathrm{U}-\mathrm{Pb}$ and $\mathrm{Lu}-\mathrm{Hf}$ isotopes. Geoscience Frontiers, 9(1), 173-189. https://doi.org/10.1016/j.gsf.2017.02.006

Petersson A., Scherstén A., Kemp A.I.S., Kristinsdóttir B., Kalvig P., Anum S. 2016. Zircon U-Pb-Hf evidence for subduction related crustal growth 
and reworking of Archaean crust within the Palaeoproterozoic Birimian terrane, West African Craton, SE Ghana. Precambrian Research, 275, 286-309. https://doi.org/10.1016/j.precamres.2016.01.006

Pigois J.-P., Groves D., Fletcher I. 2003. Age constraints on Tarkwaian paleoplacer and lode-gold formation in the Tarkwa-Damang district, SW Ghana. Mineralium Deposita, 38(6), 695-714. https://doi. org/10.1007/s00126-003-0360-5

Rosa-Costa L.T., Lafon J.M., Delor C. 2006. Zircon geochronology and $\mathrm{Sm}-\mathrm{Nd}$ isotopic study: further constraints for the Archean and Paleoproterozoic geodynamical evolution of the southeastern Guiana Shield, north of Amazonian Craton, Brazil. Gondwana Research, 10(3-4), 277-300. https://doi.org/10.1016/j.gr.2006.02.012

Sá J., Sousa L., Legrand J., Galindo A., Maia H., Fillippi R. 2014. U-Pb and $\mathrm{Sm}-\mathrm{Nd}$ data of the Rhyacian and Statherian Ortogneisses from Rio Piranhas-Seridó and Jaguaribeano Terranes, Borborema Province, Northeast of Brazil. Geologia USP. Série Cientifica, 14(3), 97-110. https://doi.org/10.5327/Z1519-874X201400030007

Santos E., Neto J., Carmona L., Armstrong R., Santos L., Mendes L. 2013. The metacarbonate rocks of Itatuba Paraíba: a record of sedimentary recycling in a Paleoproterozoic collision zone of the Borborema province, NE Brazil. Precambrian Research, 224, 454-471. https://doi. org/10.1016/j.precamres.2012.09.021

Santos L., Dantas E., dos Santos E., Santos R., Lima H. 2015. Early to Late Paleoproterozoic magmatism in NE Brazil: the Alto Moxotó Terrane and its tectonic implications for the Pre-West Gondwana assembly. Journal of South American Earth Sciences, 58, 188-209. https://doi.org/10.1016/j.jsames.2014.07.006

Santos T., Fetter A., Van Schmus W., Hackspacher P. 2009. Evidence for 2. 35 to $2.30 \mathrm{Ga}$ juvenile crustal growth in the northwest Boborema Province, NE Brazil. Geological Society, London, Special Publication, 323, 271-281. https://doi.org/10.1144/SP323.13

Santos L.C.M.L., Dantas E.L., Cawood P.A., Santos E.J, Fuck R.A. 2017. Neoarchean crustal growth and Paleoproterozoic reworking in the Borborema Province, NE Brail: insights from geochemical and isotopic data of TTG and metagranitic rocks of the Alto Moxotó Terrane. Journal of South American Earth Sciences, 79, 342-363. https://doi. org/10.1016/j.jsames.2017.08.013

Silva M.G., Coelho C.E.S., Teixeira J.B.G., Alves da Silva F.C., Silva R.A., Souza J.A.B. 2001. The Rio Itapicuru greenstone belt, Bahia, Brazil: geologic evolution and review of gold mineralization. Mineralium Deposita 36(3-4), 345-357. https://doi.org/10.1007/ s001260100173

Silva L., Armstrong R., Pimentel M., Scandolara J., Ramgrab G., Wildner W., Rosa A. 2002. Reavaliação da evolução geológica em terrenos pré-cambrianos brasileiros com base em novos dados U-Pb SHRIMP, parte III: províncias Borborema, Mantiqueira Meridional e Rio NegroJuruena. Revista Brasileira de Geociências, 32(4), 529-544. https:// doi.org/10.25249/0375-7536.2002324529544
Silva L., Costa F., Armstrong R., McNaughthon N. 2014. U-Pb SHRIMP zircon dating and $\mathrm{Nd}$ isotopes at basement inliers from northern Borborema Province, Ceará State, NE Brazil: evidences for the Archean and Paleoproterozoic crustal evolution. In: South American Symposium on Isotope Geology, 9, 175. https://doi. org/10.13140/2.1.3824.1603

Silva L., McNaughton N., Vasconcelos A., Gomes J., Fletcher I. 1997. $\mathrm{U}-\mathrm{Pb}$ SHRIMP ages in the southern State of Ceará, Borborema Province, NE Brazil: archean TTG accretion and Proterozoic crustal reworking. In: International Symposium on Granites and Associated Mineralizations, 2, 281-282.

Souza Z., Kalsbeek F., Deng X., Frei R., Kokfelt T., Dantas E., Galindo A. 2016. Generation of continental crust in the northern part of the Borborema Province, norheastern Brazil, from Archean to Neoproterozoic. Journal of South American Earth Sciences, 68, 6896. https://doi.org/10.1016/j.jsames.2015.10.006

Souza Z., Martin H., Peucat J., Jardim de Sá E., Macedo M. 2007. CalcAlkaline Magmatism at the Archean-Proterozoic Transition: the Caicó Complex Basement (NE Brazil). Journal of Petrology, 48, 2149-2185. https://doi.org/10.1093/petrology/egm055

Teixeira W., Oliveira E., Peng P., Dantas E., Hollanda M. 2017. U-Pb geochronology of the $2.0 \mathrm{Ga}$ Itapecerica graphite-rich supracrustal succession in the São Francisco Craton: tectonic matches with the North China Craton and paleogeographic inferences. Precambrian Research, 293, 91-111. https://doi.org/10.1016/j. precamres.2017.02.021

Van Schmus W., Kozuch M., Brito Neves B. 2011. Precambrian history of the Zona Transversal of the Borborema Province, NE Brazil: insights from $\mathrm{Sm}-\mathrm{Nd}$ and $\mathrm{U}-\mathrm{Pb}$ geochronology. Journal of South American Earth Sciences, 31(2-3), 227-252. https://doi.org/10.1016/j. jsames.2011.02.010

Vanderhaeghe O., Ledru P., Thiéblemont D., Egal E., Cocherie A., Tegyey M., Milési J.P. 1998. Contrasting mechanism of crustal growth: geodynamic evolution of the Paleoproterozoic granite-greenstone belts of French Guiana. Precambrian Research, 92(2), 165-193. https://doi.org/10.1016/S0301-9268(98)00074-6

Wiedenbeck M., Allé P., Corfu W.L., Griffin M.M., Oberli A.V.Q., Roddick J.C., Spiegel W. 1995. Three natural zircon standards for U-Th-Pb, Lu$\mathrm{Hf}$, trace element and Ree analyses. Geostandards Newsletter, 19(1), 1-23. https://doi.org/10.1111/j.1751-908X.1995.tb00147.x

Yang Q-Y., Santosh M., Wada H. 2014. Graphite mineralization in Paleoproterozoic khondalites of the North China Craton: a carbon isotope study. Precambrian Research, 255(2), 641-652. https://doi. org/10.1016/j.precamres.2014.04.005

Zhao G., Cawood P., Wilde S., Sun M. 2002. Review of global 2.1-1.8 orogens: implications for a pre-Rodinia supercontinent. EarthScience Reviews, 59(1-4), 125-162. https://doi.org/10.1016/S00128252(02)00073-9 